\title{
WODY OPADOWE I ICH ODPROWADZANIE
}

\section{RAINWATER AND ITS DRAINAGE}

\section{STRESZCZENIE}

Opracowanie zawiera rozważania odnośnie do statusu wód opadowych i dopuszczalnych sposobów postępowania z nimi w obowiązującym stanie prawnym, przedstawione na tle historycznym. Szersze spojrzenie nie tylko ukazuje ewolucję pewnych rozwiązań, ale przede wszystkim pozwala na lepsze zrozumienie budzących wątpliwości przepisów w tej materii, do czasu postulowanego doprecyzowania. Konieczne są również zmiany, idące w szczególności w kierunku zapewnienia racjonalnego wykorzystania wód opadowych, celem ograniczenia powstawania niekorzystnych zjawisk środowiskowych, związanych z ich nadmiarem bądź niedoborem oraz zanieczyszczeniem.

Mgr prawa, z-ca kierownika Wydziału Kontroli, Regionalny Zarząd Gospodarki Wodnej w Krakowie, doktorant w Katedrze Prawa Górniczego i Ochrony Środowiska, Wydział Prawa i Administracji, Uniwersytet Śląski w Katowicach. 


\section{Słowa kluczowe}

Status wód opadowych; wykorzystanie wód opadowych; ścieki opadowe; zmiana stanu wody na gruncie

\section{ABSTRACT}

The study covers a discussion regarding the status of rainwater and acceptable ways of dealing with it under the current legal situation, presented against the historical background. A broader view not only shows the evolution of certain solutions, but above all, allows a better understanding of questionable legislation in this matter until its proposed clarification. Changes are necessary, especially towards ensuring the rational use of rainwater, in order to reduce the occurrence of adverse environmental effects associated with its excess or deficiency as well as pollution.

\section{Keywords}

Status of rainwater; use of rainwater; sewage runoff; change in water on the ground

\section{WODY OPADOWE JAKO WODY NATURALNE}

Wody naturalne występujące w przyrodzie najczęściej dzieli się na wody atmosferyczne, powierzchniowe i podziemne ${ }^{1}$. Pierwsze $\mathrm{z}$ nich powstają z wody odparowanej w górnych warstwach atmosfery, spadającej z powrotem na ziemię podczas opadu atmosferycznego (głównie deszczu lub śniegu albo gradu), tworząc wody nazywane opadowymi (opadowo-roztopowymi lub deszczowymi), które następnie zasilają wody powierzchniowe, w postaci wód płynących w ciekach lub stoją-

1 W. Glapa, J. I. Korzeniowski, Mały leksykon górnictwa odkrywkowego, Wrocław 2005, s. 116. Do rzadkości należą inne wyróżniki wód, np. na wodę niebieską, zieloną i wirtualną. Zob. W. Majewski, Światowy Dzień Wody 2012, „Gospodarka Wodna” 2012, nr 3, s. 98-99. 
cych w jeziorach oraz sztucznych zbiornikach wodnych, zarówno bezpośrednio, jak też poprzez spływ powierzchniowy, zaś w drodze wsiąkania - wody podziemne, zlokalizowane pod powierzchnią ziemi, jako wody podskórne, gruntowe i wgłębne ${ }^{2}$. W cyklu hydrologicznym wyróżnia się dwie fazy - atmosferyczną i kontynentalną. Faza atmosferyczna obejmuje parowanie wody, przenoszenie pary wodnej w atmosferze, kondensację, a także opad atmosferyczny. Na fazę kontynentalną składa się natomiast odpływ powierzchniowy, wsiąkanie, odpływ podziemny i różne formy retencji wody ${ }^{3}$.

Istotne wydaje się więc pytanie, do jakiej kategorii wód $\mathrm{w}$ istocie przynależą wody opadowe oraz w jaki sposób należy z nimi postępować, skoro pomimo czasowości samoistnego ich występowania na powierzchni ziemi, mają zasadniczy wpływ na obieg wody w przyrodzie ${ }^{4}$, przez co w ramach gospodarowania wodami, realizowanego zasadniczo wedle przepisów obowiązującej obecnie ustawy z dnia 18 lipca 2001 r. Prawo wodne ${ }^{5}$, nie mogą zostać pominięte. Aby udzielić wszak precyzyjnej odpowiedzi na postawione pytanie, trzeba odnieść się najpierw do stanu poprzedniego, z którego wywodzą się teraźniejsze rozwiązania względem wód opadowych, co dzięki szerszemu kontekstowi pozwoli lepiej zrozumieć ich znaczenie.

2 J. Szturc, Hydrologia stosowana w zarysie, Bielsko-Biała 1995, s. 11-20; J. Dowgiałło, A. S. Kleczkowski, T. Macioszczyk, A. Różkowski, Słownik hydrogeologiczny, Warszawa 2002, s. 140, 226, 284, 296, 301.

3 E. Bajkiewicz-Grabowska, Z. Mikulski, Hydrologia ogólna, Warszawa 2008, s. 19-20.

4 Szczegółowo problematykę krążenia wody w przyrodzie wraz z klasyfikacją opadów omawia m.in. J. Lambor, Hydrologia inżynierska, Warszawa 1971, s. 9-11, a także P. Żukowski, Degradacja hydrosfery (przegląd problematyki i metod badań), Rzeszów 1994, s. 6-10.

5 Tj. Dz.U. z 2012 r., poz. 145 ze zm. 


\section{WODY OPADOWE W OKRESIE OBOWIĄZYWANIA USTAWY WODNEJ Z 1922 R.}

Już w ustawie wodnej z dnia 19 września 1922 r. ${ }^{6}$, dokonując $\mathrm{w}$ art. 1 podziału wód na publiczne i prywatne, zaliczono z mocy prawa do tych ostatnich wodę z opadów atmosferycznych oraz jej odpływy, dopóki nie spłyną na cudzy grunt, albo do cudzej wody prywatnej lub do wody publicznej (art. 4 lit. a i b). Zatem własność gruntu została rozciągnięta na wody pochodzące z opadu z chwilą zetknięcia się ich z powierzchnią ziemi. Z kolei wpadając do wód płynących i mieszając się z nimi, opad dzielił ich los, odmienny w zależności od tego, czy wody płynące stanowiły wody wydzielone, czy też niewydzielone ${ }^{7}$.

Właściciel gruntu mógł, co do zasady, swobodnie rozporządzać wodą znajdującą się na powierzchni jego gruntu, w szczególności używać i zużywać wodę oraz odprowadzać ją, czy też obniżać lub podnosić zwierciadło wody, jak również trwale zbierać wodę przez wstrzymanie odpływu (art. 36 ust. 1 i 2 ustawy wodnej). Jednocześnie z tej racji, iż wody z opadów przy dużych spadkach przemieszczają się częstokroć na grunty sąsiednie poprzez spływ powierzchniowy i mogą powodować w nich szkody, wprowadzono dla zapobieżenia jego zwiększeniu bądź zatamowaniu pewne ograniczenia, względem dokonywania zmian w odpływie, które nie obejmowały jednak zmian w zakresie gospodarczego użytkowania gruntu (zmiana kierunku orki, stawianie budynków i ogrodzeń, itp.). Właściciel gruntów wyżej położonych nie mógł mianowicie samowolnie zmienić naturalnego odpływu wody opadowej ze szkodą w gruntach niżej położonych, podobnie jak właściciel gruntów niżej położonych nie mógł wstrzymywać naturalnego odpływu wody opadowej ze szkodą dla gruntu wyżej położonego (art. 17 ust. 1-4

6 Tj. Dz.U. z 1928 r. Nr 62, poz. 574 ze zm.

7 T. Dybowski, S. M. Grzybowski, Z. K. Nowakowski, Zagadnienia cywilistyczne prawa wodnego, Warszawa 1957, s. 259. 
ustawy wodnej), chyba że dochodziło do niego w sposób sztucz$n y^{8}$. Obie te zasady określano mianem prawa odpływu ${ }^{9}$.

Nie zezwolono też na wpuszczanie do jezior wody $i$ innych cieczy (art. 18 ust. 2 ustawy wodnej), a także wprowadzanie lub wpuszczanie do ziemi materii, które by zanieczyszczały wodę podziemną, wodę płynącą lub jezioro ze szkodą dla innych (art. 19 ust. 2 pkt 2 ustawy wodnej). Niemniej wody opadowe, podobnie jak i inne wody pochodzące $\mathrm{z}$ gospodarstwa, wolno było swobodnie odprowadzać do wód płynących i jezior należących do wód płynących. Odbywało się to w ramach powszechnego użytkowania wód bez pozwolenia wodnoprawnego (jeśli tylko nie zostały zanieczyszczone w urządzeniach kanalizacyjnych), z wyjątkiem działań ponad miarę takowego użytkowania, wyszczególnionych w art. 25 ust. 1-3 ustawy wodnej, kiedy wymagano zezwolenia władzy wodnej (starostów) - tzw. użytkowanie wzmocnione ${ }^{10}$.

Należy dodać, że szczegółowe kwestie dotyczące odprowadzania wód opadowych na terenach zurbanizowanych normowały akty wydane na podstawie art. 408 pkt 14 rozporządzenia Prezydenta RP z dnia 16 lutego 1928 r. o prawie budowlanym i zabudowaniu osiedli1 ${ }^{11}$. Mam tu na myśli zarządzenie Ministra Spraw Wewnętrznych z dnia 1 sierpnia 1936 r. w sprawie przepisów miejscowych o zaopatrywaniu w wodę oraz o usuwaniu nieczystości i wód opadowych $\mathrm{w}$ mieście stołecznym Warszawie $^{12}$, które w $\S 37$ ust. 1 pkt c przewidywało, że co do zasady do miejskiej sieci kanalizacyjnej miały być odprowadzane z oddzielnych nieruchomości drogą podziemną wody z opadów atmosferycznych, a także rozporządzenie Ministrów Budownictwa oraz Gospodarki Komunalnej z dnia 9 października 1956 r. w sprawie urządzeń instalacji wodociągowych i kanalizacyj-

8 Zob. orzeczenie Sądu Najwyższego I C 973/37 z dnia 27 kwietnia 1938 r., publ. OSN(C) 1939/2/90.

9 A. Neuman, Materjalne i formalne prawo wodne, Stanisławów 1930, s. 5.

10 Z. Rybicki, Pozwolenie wodno-prawne $w$ systemie gospodarki planowej $P R L$, Warszawa 1958, s. 59-60.

11 Tj. Dz.U. z 1939 r. Nr 34, poz. 216 ze zm.

12 M.P. Nr 187, poz. 349. 
nych $^{13}$, nakazujące odprowadzanie w taki sam sposób owych wód (już niezależnie od miejscowości), jeżeli tylko kanalizacja publiczna była ogólnospławna lub istniały na danej ulicy odrębne przewody służące do odprowadzania wód opadowych (§ 20 pkt 3). Równocześnie zabronione było odprowadzanie wody deszczowej do pionowych przewodów spustowych wewnętrznych urządzeń kanalizacyjnych oraz spuszczanie wód brudnych do przewodów spustowych deszczowych ( $§ 45$ wspomnianego rozporządzenia).

Sprawdzanie prawidłowości odprowadzania nieczystości i wód opadowych, jak również zakładanie urządzeń kanalizacyjnych oraz zaprowadzenie odpowiednich sposobów zbierania, przechowywania i usuwania nieczystości i wód opadowych (w zależności od ilości mieszkańców) należało tymczasem do obowiązków gmin, wynikających z art. 2 ust. 1-3 rozporządzenia Prezydenta RP z dnia 16 marca 1928 r. o usuwaniu nieczystości i wód opadowych ${ }^{14}$. Warto też dostrzec, że wydane na podstawie wspomnianego aktu rozporządzenie Ministrów Spraw Wewnętrznych i Opieki Społecznej z dnia 8 stycznia 1938 r. o korzystaniu z urządzeń wodociągowych oraz urządzeń do usuwania nieczystości i wód opadowych ${ }^{15}$ nakładało na właścicieli i zarządców nieruchomości obowiązek utrzymywania w stanie zdatnym do użytku urządzeń służących m.in. do odprowadzania wód opadowych. Rozporządzenie Ministra Gospodarki Komunalnej z dnia 2 września 1950 r. w sprawie określenia warunków, jakim powinny odpowiadać ścieki wpuszczane do zbiorników wód powierzchniowych i do ziemi ${ }^{16}$, zawierało natomiast definicję ścieków, za które uznawano wody opadowe ujęte w przewody otwarte lub zakryte i odprowadzane osobno lub łącznie z wodami zużytymi z osiedli bądź poszczególnych nieruchomości (§ 1 ust 2). W sposób szczegółowy określało nadto, kiedy i do jakich kategorii wód powierzchniowych lub

13 Dz.U. Nr 48, poz. 216 ze zm.

14 Tj. Dz.U. z 1939 r. Nr 90, poz. 581.

15 Dz.U. Nr 11, poz. 76 ze zm.

16 Dz.U. Nr 41, poz. 371. 
do ziemi mogły być wpuszczane ścieki, w tym również zaklasyfikowane do nich wody opadowe.

Rozporządzenie Prezydenta RP o usuwaniu nieczystości i wód opadowych zostało uchylone przez ustawę z dnia 22 kwietnia 1959 r. o utrzymaniu czystości i porządku w miastach i osiedlach ${ }^{17}$, w której przez pojęcie nieczystości rozumiano m.in. wody opadowe, ale wyłącznie na ulicach, placach i innych miejscach przeznaczonych do powszechnego użytku (art. 2 ust. 1), a ściekami miejskimi nazywano ścieki spływające do miejskich sieci kanalizacyjnych, odprowadzających nieczystości płynne do wód powierzchniowych lub do ziemi (art. 2 ust. 2). Zapewnienie ich usuwania i unieszkodliwiania oraz planowanie i budowa urządzeń służących temu celowi należały do obowiązków rad narodowych miast i osiedli (art. 3 ust. 1-3 ustawy o utrzymaniu czystości i porządku w miastach i osiedlach), które mogły także nałożyć na właścicieli i użytkowników nieruchomości już zabudowanych obowiązek podłączenia do sieci. Na podstawie art. 7 ust. 1 cytowanej ustawy wydane zostało ponadto rozporządzenie Ministra Gospodarki Komunalnej z dnia 11 lutego 1963 r. w sprawie warunków, jakim powinny odpowiadać ścieki odprowadzane do miejskich urządzeń kanalizacyjnych ${ }^{18}$. Zgodnie z $\S 1$ tego rozporządzenia za ścieki uważano nie tylko wody zużyte, lecz także wody opadowe oraz pochodzące $\mathrm{z}$ drenażu miejskiego, ujęte $\mathrm{w}$ przewody otwarte lub kryte. Ich odprowadzanie do miejskich sieci kanalizacyjnych było dopuszczalne po spełnieniu odpowiednich parametrów fizyko-chemicznych (określonych w $\S 2$ i 3). Przy czym, $\mathrm{w}$ razie występowania sieci składającej się z odrębnych przewodów do odprowadzania wód opadowych i odrębnych dla innych ścieków, zakłady odprowadzające ścieki do miejskiej sieci kanalizacyjnej mogły je odprowadzać tylko do przewodów sieci ściekowej (§ 5). W art. 7 ust. 2 ustawy o utrzymaniu czystości i porządku w miastach i osiedlach Ministra Żeglugi i Gospodarki Wodnej upoważniono z kolei do określenia w drodze rozporządzenia, jakim warunkom powinny odpowiadać ścieki odprowa-

17 Dz.U. Nr 27, poz. 167 ze zm.

18 Dz.U. Nr 15, poz. 80. 
dzane do wód powierzchniowych i do ziemi na terenie miast, osiedli i gromad. Ten ostatni przepis został jednak uchylony na mocy art. 31 pkt 3 ustawy z dnia 31 stycznia 1961 r. o ochronie wód przed zanieczyszczeniem ${ }^{19}$.

W art. 1 ust. 2 ustawy o ochronie wód przed zanieczyszczeniem zdefiniowano zanieczyszczenie wód, jako wywołanie w nich takich zmian fizycznych, chemicznych lub biologicznych, przez wprowadzenie do nich nadmiernych ilości substancji stałych, płynnych, gazowych, jak również nadmiernych ilości energii, substancji promieniotwórczych lub innych, które sprawiały, że wody nie nadawały się do normalnego użytkowania do celów komunalnych, przemysłowych, rolniczych, rybackich lub innych. Normy dopuszczalnych zanieczyszczeń określone zostały w wydanym rozporządzeniu z dnia 28 lutego 1962 r. w sprawie norm dopuszczalnych zanieczyszczeń wody oraz warunków, jakim powinny odpowiadać ścieki odprowadzane do wody i do ziemi ${ }^{20}$, w odniesieniu do tego, czy chodziło o ścieki socjalno-bytowe, czy też o przemysłowe. Brak wyszczególnienia wód pochodzących z opadów oznaczał, że ich odprowadzanie nie było wówczas w sposób czytelny kwalifikowane za jednoczesne wprowadzanie ścieków do wód.

\section{WODY OPADOWE W OKRESIE OBOWIAZZYWANIA PRAWA WODNEGO Z $1962 \mathrm{R}$.}

Ustawa z dnia 30 maja 1962 r. Prawo wodne ${ }^{21}$ zastąpiła nie tylko ustawę wodną, lecz również obowiązującą przez niewiele ponad rok ustawę o ochronie wód przed zanieczyszczeniem. Zerwała ona z podziałem wód na publiczne i prywatne, co wynikało z ówczesnego modelu społeczno-gospodarczego ${ }^{22}$. Miała

19 Dz.U. Nr 5, poz. 33.

20 Dz.U. Nr 17, poz. 75.

21 Dz.U. Nr 34, poz. 158 ze zm.

22 Zob. S. Szer, O własności wód, „Przegląd Ustawodawstwa Gospodarczego" 1961, nr 2 (152), s. 44-45. 
charakter nacjonalizacyjny w stosunku do części wód, jakie według ustawy wodnej stanowiły własność prywatną (niewydzielone wody płynące) ${ }^{23}$. Zgodnie bowiem z art. 1 ust. 1 prawa wodnego z 1962 r. przyjęto zasadę państwowej własności wód, z istotnym wyjątkiem dotyczącym wód powierzchniowych stojących oraz wód w studniach i rowach, na które nadal, tak jak w ustawie wodnej z 1922 r., rozciągała się własność gruntu. Warto w tym miejscu nadmienić, że spór o to, czy własność wód stojących znajdujących się $\mathrm{w}$ granicach nieruchomości jest prawem podmiotowym odrębnym od własności gruntowej, czy też owe wody stanowią własność właściciela nieruchomości dlatego, że są częścią składową jego nieruchomości, pozostał po dziś dzień nierozstrzygnięty ${ }^{24}$.

W art. 6 ust. 1 Prawa wodnego z 1962 r. wszystkie wody nazwano wodami śródlądowymi, poza morskimi wodami wewnętrznymi i wodami morza terytorialnego, ale akurat do tych ostatnich przepisy ustawy miały jedynie częściowe zastosowanie (art. 5 ust. 1 cytowanej ustawy) ${ }^{25}$. Dokonano także pewnego usystematyzowania, kierując się zasadniczo podziałem znanym w hydrologii ${ }^{26}$. Przyjęto wszak w myśl art. 7 pkt 1 i 2 Prawa wodnego z 1962 r. dość klarowny podział wód śródlądowych na dwa podstawowe rodzaje - wody powierzchniowe (znajdujące się na powierzchni ziemi) i wody podziemne (znajdujące się pod powierzchnią ziemi). Ponadto w art. 8 pkt 1 i 2 tej ustawy przeprowadzono dalszy podział, poprzez wyróżnienie spośród wód powierzchniowych wód płynących (znajdujących się w rzekach, w jeziorach lub zbiornikach, z których cieki wypływają

23 Zob. uchwałę Sądu Najwyższego III CZP 28/71 z dnia 8 listopada 1971 r., publ. OSNC 1972/3/43.

24 R. Mikosz, Granice przestrzenne nieruchomości, [w:] E. Gniewek (red.), Prawo rzeczowe, t. 3, Warszawa 2013, s. 373-374. Ponadto zob. B. Rakoczy, Własność wód w prawie polskim, „Przegląd Prawa Ochrony Środowiska” 2013, nr 1, s. 23-24.

25 Zob. rozporządzenie Rady Ministrów z dnia 17 lipca 1965 r. w sprawie rozciągnięcia niektórych przepisów prawa wodnego na morskie wody wewnętrzne i morze terytorialne, Dz.U. Nr 31, poz. 205.

26 Zob. E. Czetwertyński, A. Szuster, Hydrologia i hydraulika, Warszawa 1973, s. 61-62. 
lub do których uchodzą, potokach górskich, kanałach i innych ciekach o przepływach stałych lub okresowych oraz w źródłach, z których cieki biorą początek) oraz wód stojących (znajdujących się w innych jeziorach, stawach i innych zbiornikach - tzn. nieprzepływowych).

W interesującej nas tematyce mogłoby się więc wydawać, że w powyższej klasyfikacji pominięto całkowicie wody opadowe, choć przecież w hydrologii zalicza się je do wód powierzchniowych ${ }^{27}$. Niemniej trzeba zwrócić uwagę, iż w świetle art. 7 pkt 1 in fine Prawa wodnego z 1962 r. wody znajdujące się na powierzchni ziemi dopóty, dopóki nie wsiąknęły w grunt lub nie wyparowały również należało traktować jako wody powierzchniowe, nawet gdy nie zostały wymienione w art. 8 pkt 1 tej ustawy. Obojętne było przy tym, czy pochodziły z opadów atmosferycznych, czy też stanowiły wysiąki z gruntu ${ }^{28}$.

W ramach zwykłego korzystania z wód właścicielowi gruntu przysługiwało dla zaspokojenia potrzeb własnych i swojego gospodarstwa domowego lub rolnego prawo do korzystania z wód stanowiących jego własność (art. 36 ust. 1 Prawa wodnego z 1962 r.). Jednakowoż, zgodnie z art. 38 Prawa wodnego z 1962 r., właściciel gruntu nie mógł zmieniać istniejącego stanu wody na gruncie, jeśli tylko zmiana ta byłaby przyczyną szkodliwego naruszenia stosunków wodnych, a w szczególności spuszczać wody na grunty sąsiednie oraz trwale obniżać poziom zwierciadła powierzchniowych wód stojących oraz wód w studniach i rowach. Oprócz tego, na właścicielu gruntu ciążył obowiązek usunięcia takich przeszkód i zmian w naturalnym odpływie wody na jego gruncie, które przynosiły szkody właścicielom nieruchomości sąsiednich albo gospodarce wodnej (art. 39 Prawa wodnego z 1962 r.). W istocie nie zaistniały zatem jakieś poważniejsze różnice $\mathrm{w}$ stosunku do stanu wcześniejszego. Jedyna większa odmienność wynikała z pominięcia wyłączenia nałożonych na właścicieli gruntu zakazów do zmian

27 Zob. A. Tuszko, Hydraulika i wodociagi, Warszawa 1971, s. 140.

28 W. Tarasiewicz, S. Surowiec, Z. Rybicki, Prawo wodne. Komentarz, przepisy wykonawcze $i$ zwiąkowe, Warszawa 1965, s. 22-24, a także Z. Mikucki, J. Kowalewski, Ekonomika i prawo wodne, Warszawa 1970, s. 229. 
spowodowanych gospodarczym użytkowaniem gruntu, a także z przyjętego administracyjnego trybu dochodzenia roszczeń. Powiatowe organy administracji wodnej władne były do wydawania, na wniosek poszkodowanych, decyzji administracyjnych nakazujących właścicielom gruntów wykonanie urządzeń zapobiegających szkodom albo przywrócenie stanu pierwotnego (art. 40 Prawa wodnego z 1962 r.).

W kwestii odprowadzania wód opadowych do wód płynących lub wód stojących oraz ziemi warto zauważyć, że w art. 43 ust. 2 Prawa wodnego z 1962 r. do szczególnego korzystania z wód wymagającego pozwolenia wodnoprawnego zaliczono wprowadzanie do wód śródlądowych oraz do morskich wód wewnętrznych i morza terytorialnego substancji lub energii, które mogły je szkodliwie zanieczyścić (pkt 3), a także odprowadzanie wody w celu odwodnienia gruntu lub obiektu budowlanego, kiedy urządzenia do odprowadzania wody przechodziły przez cudzy grunt, z wyjątkiem melioracji wodnych półpodstawowych i szczegółowych ${ }^{29}$, wykonywanych na potrzeby rolnictwa (pkt 6). Pewne wątpliwości budziło jednak to, że sam spływ wyłącznie wód opadowych niosących nieczystości z terenów zurbanizowanych nie był wówczas uważany za niebezpieczny pod względem sanitarnym i dopuszczano do ich odprowadzania z sieci kanalizacji deszczowej w obrębie miast bez oczyszczania wprost do odbiorników ${ }^{30}$, a odnośnie do odwodnień nie sposób było ustalić, o odprowadzanie jakiego rodzaju wód tak naprawdę chodziło ustawodawcy. Bez wątpienia wszakże przepisy dotyczące szczególnego korzystania z wód znajdowały również zastosowanie przy wprowadzaniu zanieczyszczonych wód opadowych do ziemi, co wynikało z art. 82 ust. 4 Prawa wodnego z 1962 r.

29 Pojęcia melioracji wodnych półpodstawowych i szczegółowych zostały zdefiniowane w art. 2 ust. 1 pkt 2 i 3 ustawy z dnia 22 maja 1958 r. o popieraniu melioracji wodnych dla potrzeb rolnictwa, tj. Dz.U. z 1963 r. Nr 42, poz. 237 ze zm.

${ }^{30}$ W. Błaszczyk, A. Nowakowska-Błaszczyk, Projektowanie sieci kanalizacyjnej, [w:] M. Chudzicki (red.), Projektowanie sieci kanalizacyjnej, Warszawa 1971, s. 424-426. 
Pozwolenia na odprowadzanie wody w celu odwodnienia wydawał powiatowy organ administracji wodnej, a wojewódzki organ administracji wodnej $\mathrm{w}$ przypadku wprowadzania substancji lub energii mogących zanieczyścić wody (art. 44 ust. 1 i 2 Prawa wodnego z 1962 r.).

Rada Ministrów wydała rozporządzenie z dnia 9 czerwca 1970 r. w sprawie norm dopuszczalnych zanieczyszczeń wód i warunków wprowadzania ścieków do wody i do ziemi ${ }^{31}$, w którym zaniechano odrębnych rozwiązań w zależności od rodzaju ścieków, co, mając na względzie ustawową definicję ścieków, pozwalało w zasadzie na zakwalifikowanie jako ścieki zanieczyszczonych wód opadowych. Na mocy § 8 wspomnianego rozporządzenia zabroniono także wprowadzania zanieczyszczeń do wód podziemnych. Zgodnie z ustawą w ogóle nie wymagano natomiast pozwolenia wodnoprawnego na odprowadzanie wody za pomocą rowów otwartych i rurociągów, które istniały co najmniej od pięciu lat przed dniem wejścia w życie ustawy i służyły do odwodnienia gruntu lub obiektu budowlanego, a ewentualne spory tej natury rozstrzygał powiatowy organ administracji wodnej (art. 164 ust. 1 i 2 Prawa wodnego z 1962 r.).

Do tego dodajmy, że gdy chodzi o odprowadzanie wód opadowych z obiektów budowlanych, to przepisy uległy wcześniejszej zmianie, bo już rok przed wejściem w życie Prawa wodnego z 1962 r. rozporządzenie Prezydenta RP o prawie budowlanym i zabudowaniu osiedli zostało uchylone na mocy ustawy z dnia 31 stycznia 1961 r. Prawo budowlane ${ }^{32}$. Wydany został też akt wykonawczy do tej ustawy w postaci rozporządzenia Przewodniczącego Komitetu Budownictwa, Urbanistyki i Architektury z dnia 21 lipca 1961 r. w sprawie warunków technicznych, jakim powinny odpowiadać obiekty budowlane budownictwa powszechnego ${ }^{33}$, w którym z racji istnienia wymogu wyposażenia okapów dachów, stropodachów lub tarasów budynków (o co najmniej dwóch kondygnacjach) w rynny i rury

31 Dz.U. Nr 17, poz. 144.

32 Dz.U. Nr 7, poz. 46 ze zm.

33 Dz.U. Nr 38, poz. 196 ze zm. 
spustowe, czy też rzygacze ( $§ 27$ ust. 1 i 2), dopuszczano odprowadzanie wody opadowej spustami bezpośrednio do kanalizacji, albo poza obiekt - korytkami ściekowymi wykonanymi z materiałów trwałych, na odległość zapobiegającą podmyciu fundamentów. Osoby fizyczne i prawne, będące właścicielami terenów położonych $\mathrm{w}$ granicach administracyjnych miast i osiedli, były także obowiązane pokrywać część kosztów pierwszego urządzenia kanalizacyjnych urządzeń komunalnych, odpowiadającą wartości ich nieruchomości powstałemu wskutek wykonania tych urządzeń, stosownie do art. 28 ust. 1 ustawy z dnia 14 lipca 1961 r. o gospodarce nieruchomościami w miastach i osiedlach ${ }^{34}$. Sposób ustalenia wysokości kosztów określono w akcie wykonawczym ${ }^{35}$.

\section{WODY OPADOWE W OKRESIE OBOWIĄZYWANIA PRAWA WODNEGO Z 1974 R.}

Prawo wodne z 1962 r. zostało zastąpione ustawą z dnia 24 października 1974 r. Prawo wodne ${ }^{36}$. Co do zasady znajdowała ona zastosowanie wyłącznie do wód śródlądowych (art. 7 ust. 1), dzielących się na wody powierzchniowe i wody podziemne (art. 6 ust. 2). Jednocześnie nie zostały zdefiniowane w żaden sposób ani wody powierzchniowe, ani podziemne. Podobnie też jak w Prawie wodnym z 1962 r. dokonano w art. 6 ust. 3 Prawa wodnego z 1974 r. podziału tych pierwszych na wody płynące (w rzekach, potokach górskich, kanałach i innych ciekach o przepływach stałych lub okresowych oraz w źródłach, z których cieki biorą początek) oraz stojące (znajdujące

34 Tj. Dz.U. z 1969 r. Nr 22, poz. 159 ze zm.

35 Chodzi o rozporządzenie Rady Ministrów z dnia 26 lipca 1962 r. w sprawie pokrywania kosztów pierwszego urządzenia ulic i placów komunikacyjnych oraz innych urządzeń komunalnych, tj. Dz.U. z 1969 r. Nr 5, poz. 41 ze zm.

36 Dz.U. Nr 38, poz. 230 ze zm. 
się $\mathrm{w}$ jeziorach i innych zbiornikach). W doktrynie dostrzeżono wprawdzie całkowite pominięcie w tym aspekcie wód opadowych i brak powtórzenia przepisu, zawartego wcześniej w ustawie wodnej z 1922 r., który wskazywał, że do właścicieli gruntów należy także woda z opadów atmosferycznych (art. 4), ale podnoszono jednocześnie, iż nie dawało to żadnych podstaw do przyjęcia, że stan prawny uległ zmianie, albowiem do wód opadowych jako części składowych gruntu miały wprost zastosowane przepisy ustawy z dnia 23 kwietnia 1964 r. kodeks cywilny ${ }^{37}$, tj. art. 47 k.c. ${ }^{38}$

W mojej ocenie pomocne wydaje się raczej sięgnięcie do ówczesnych przepisów Prawa wodnego, dotyczących wód stojących. Odnośnie do powierzchniowych wód stojących (oraz wód w studniach i rowach) Prawo wodne z 1974 r. dalej utrzymywało wszak regułę, zgodnie z którą wody te stanowiły własność właściciela gruntu (art. 2) i mógł on nadal swobodnie ich używać celem zaspokojenia potrzeb własnych i gospodarstwa domowego oraz gospodarstwa rolnego, w ramach zwykłego korzystania z wód (art. 49 ust. 1), odbywającego się bez potrzeby posiadania pozwolenia wodnoprawnego, z nielicznymi wyjątkami, wykraczającymi ponad miarę takowego korzystania i odnoszącymi się w szczególności do poboru wody na cele przemysłowe (art. 49 ust. 1 i 3).

Właścicielowi zakazano jednak zmianę stanu wody na gruncie, istniejącego co najmniej od pięciu lat ${ }^{39}$, jeżeli taka zmiana mogłaby szkodliwie oddziaływać na grunty sąsiednie. W przeciwnym bowiem przypadku (bądź w razie szkodliwego wpływu na gospodarkę wodną) wójt (burmistrz, prezydent mia-

37 Dz.U. Nr 16, poz. 93 ze zm.

38 S. Rudnicki, O własności wód, „Nowe Prawo” 1982, nr 7-8, s. 81-82.

39 Zmiana stanu wody przy braku szkodliwego jej oddziaływania na nieruchomości sąsiednie, jak również zmiana stanu istniejącego krócej niż lat pięć, jeśli nawet mogła szkodliwie oddziaływać na nieruchomości sąsiednie, nie była przez ustawę z 1974 r. zakazana. Nie wyłączało to jednak dochodzenia roszczeń na drodze sądowej. Zob. wyrok Sądu Najwyższego z dnia 9 lutego 1981 r. - CR 469/80, publ. OSNC 1981/12/237. 
sta ${ }^{40}$ władny był nakazać właścicielowi gruntu przywrócenie do stanu poprzedniego lub wykonanie urządzeń zapobiegających szkodom, a w razie braku gospodarczego uzasadnienia mógł nałożyć inny obowiązek, w postaci zapłaty odszkodowania $^{41}$ (art. 50 ust. 1 i 2 Prawa wodnego z 1974 r.) ${ }^{42}$. Problematyczne było jednak, czy przepis ten znajdował zastosowanie tylko kiedy szkoda stanowiła następstwo zwykłego korzystania wód, czy także skutek innych działań lub zaniechań właściciela gruntu $^{43}$. Z kolei starosta ${ }^{44}$, po dojściu do zmiany stanu wody na gruncie, mógł wydać decyzję o wykonaniu przez państwowe jednostki organizacyjne koniecznych robót lub urządzeń, jeżeli usunięcie zaistniałych zmian byłoby gospodarczo nieuzasadnione, a wykonanie tych robót i urządzeń miało na celu trwałe

40 Pierwotnie organem właściwym do wydania decyzji w tej sprawie był naczelnik gminy. Art. 49 ust. 2 został zmieniony przez art. 33 pkt 19 ustawy z dnia 24 lipca 1998 r. o zmianie niektórych ustaw określających kompetencje organów administracji publicznej - w związku z reformą ustrojową państwa, Dz.U. Nr 106, poz. 668.

41 Wydanie decyzji administracyjnej nakazującej właścicielowi gruntu przywrócenie stosunków wodnych do stanu poprzedniego lub wykonanie urządzeń zapobiegającym szkodom nie wyłączało dochodzenia roszczeń o naprawienie szkody na drodze sądowej. Zob. wyrok Sądu Najwyższego z dnia 17 stycznia 1989 r. - III CZP 107/88, publ. OSNC 1990/1/6.

42 Pięcioletni termin, o którym mowa w art. 50 ust. 1 Prawa wodnego z 1974 r. nie miał zastosowania do nakazania właścicielowi przywrócenia gruntu do stanu poprzedniego lub wykonania urządzeń zapobiegającym szkodom albo do nałożenia obowiązku zapłaty odszkodowania. Zob. wyrok Sądu Najwyższego z dnia 12 lipca 2000 r. - III RN 2/00, publ. OSNP 2001/9/291.

43 Zob. R. Mikosz, Glosa do wyroku Sądu Najwyższego z dnia 9 lutego 1981 r. - I CR 469/80, „Orzecznictwo Sądów Polskich Komisji Arbitrażowych” 1983, z 9, poz. C 194, s. 463-466.

44 Pierwotnie organem właściwym do wydania decyzji w tej sprawie był naczelnik powiatu. Prawo wodne z 1974 r. zostało jednak wydane niedługo przed reformą wprowadzoną ustawą z dnia 28 maja 1975 r. o dwustopniowym podziale administracyjnym Państwa oraz o zmianie ustawy o radach narodowych, Dz.U. Nr 16, poz. 91, która zniosła powiaty, a wydawanie takich decyzji powierzono naczelnikom gminy, stosownie do art. 37 wymienionej ustawy. Zob. E. Jabłoński, W. Wołłejko, Prawo wodne oraz przepisy wykonawcze $i$ związkowe, Warszawa 1979, s. 10-13. Następnie po przywróceniu powiatów art. 51 Prawa wodnego z 1974 r. został zmieniony przez art. 33 pkt 21 ustawy o zmianie niektórych ustaw określających kompetencje organów administracji publicznej - w związku z reformą ustrojową państwa. 
polepszenie stosunków wodnych na gruncie. Właściciel gruntu był obowiązany nie tylko umożliwić wykonanie owych robót i urządzeń, ale również ponieść ich koszty, stosownie do odniesionej korzyści (art. 51 Prawa wodnego z 1974 r.) ${ }^{45}$. Dopuszczalna była ponadto taka zmiana stosunków wodnych na gruntach stanowiących własność zainteresowanych właścicieli, która nie wpływała szkodliwie na nieruchomości sąsiednie oraz nie dotyczyła wprowadzania ścieków do wody lub do ziemi. Zatwierdzona przez wójta (burmistrza, prezydenta miasta) ugoda zastępowała pozwolenie wodnoprawne, a decyzja w tej sprawie była ostateczna (art. 35 ust. 1 i 2 Prawa wodnego z 1974 r.).

Zajmując się $\mathrm{w}$ dalszej części sprawą odprowadzania wód opadowych do wód powierzchniowych, zauważmy, że w art. 20 ust. 1 Prawa wodnego z 1974 r. nie wymieniono literalnie czynności wymagających uzyskania pozwolenia wodnoprawnego. Wskazano jedynie, iż chodziło o korzystanie z wód, wykraczające poza korzystanie powszechne i zwykłe oraz wykonywanie urządzeń wodnych, ale z przepisów art. 53 ust. 2 pkt 2 i 5 tej ustawy można wyciągnąć wniosek, że na odprowadzanie do wód lub ziemi zanieczyszczonych wód opadowych, jak też wód odprowadzanych za pomocą urządzeń przechodzących przez grunt innego właściciela, wymagane było pozwolenie wodnoprawne ${ }^{46}$. Wyjątek stanowiło odprowadzanie do wód powierzchniowych wód z wykopów budowlanych ${ }^{47}$.

45 Jak podnoszono w literaturze przepis ów znajdował zastosowanie, kiedy zakłócenie stosunków wodnych miało charakter lokalny, a przywrócenie stanu poprzedniego nie przyniosłoby zadowalających rezultatów, skutkując utrudnieniem prawidłowego zagospodarowania nieruchomości, wobec czego zaistniała potrzeba przeprowadzenia tzw. „małej melioracji”. Zob. S. Surowiec, W. Tarasiewicz, T. Zwięglińska, Prawo wodne. Komentarz. Przepisy wykonawcze, Warszawa 1981, s. 100-101.

46 Co do zasady organem właściwym do wydania pozwolenia wodnoprawnego był starosta, a wojewoda lub Minister Ochrony Środowiska, Zasobów Naturalnych i Leśnictwa jedynie w enumeratywnie wyliczonych przypadkach (art. 55 ust. 1 Prawa wodnego z 1974 r.). Patrz: przypis 44.

47 Zob. § 1 pkt 3 rozporządzenia Rady Ministrów z dnia 11 marca 1985 r. w sprawie rodzajów szczególnego korzystania z wód oraz wykonywania i eksploatacji urządzeń wodnych niewymagających pozwolenia wodnoprawnego, Dz.U. Nr 13, poz. 55. 
W myśl art. 18 ust. 1 pkt 1 Prawa wodnego z 1974 r. w pierwotnym jego brzmieniu definicja ścieków była co prawda zbliżona do omawianej wcześniej w Prawie wodnym z 1962 r., ale dla usunięcia dwuznaczności względem wód opadowych, wprowadzono dodatkowo w ustawie z 1974 r. art. 18 ust. 2 pkt 3, stanowiący, iż przepisy dotyczące ścieków stosuje się odpowiednio m.in. do zanieczyszczonych wód opadowych. Rodzaj oraz wielkości dopuszczalnych zanieczyszczeń zależne były od klasy czystości odbiornika ${ }^{48}$ i określone zostały w aktach wykonawczych wydanych na podstawie art. 62 ust. 3 Prawa wodnego z $1974 \mathrm{r}^{49}$ Nie było przy tym znaczące, czy wody opadowe zostały zanieczyszczone w sposób naturalny, czy też sztuczny. Za wprowadzanie ścieków będących wodami opadowymi do wód lub ziemi nie wymagano uiszczenia opłaty należnej z tytułu szczególnego korzystania z wód ${ }^{50}$. Ścieki takie mogły być wykorzystywane rolniczo, zgodnie z art. 63 ust. 2 Prawa wodnego z 1974 r., w tym zwłaszcza poprzez nawadnianie użytków rolnych ${ }^{51}$. Niedopuszczalne było też wprowadzanie ścieków do wód podziemnych. Rolnicze wykorzystanie ścieków odbywało się w ramach zwykłego, albo szczególnego, korzystania z wód (art. 49 ust. 2 i art. 53 ust. 2 pkt 2 Prawa wodnego z 1974 r.).

Początkowo nie określono, czy każde wody opadowe niosące zanieczyszczenia należało traktować jako wody zanieczyszczone. Pewien wyznacznik mógł stanowić w tej materii dopiero przepis art. 3 pkt 5 lit. e ustawy z dnia 27 czerwca 1997 r. o od-

48 Na gruncie ówczesnego stanu prawnego ujęte w formie tabelarycznej wielkości najważniejszych dopuszczalnych zanieczyszczeń śródlądowych wód powierzchniowych w trzech klasach czystości podaje: J. Piekarski, Prawo wodne i przepisy wykonawcze, Warszawa 1979.

49 Zob. rozporządzenie Ministra Ochrony Środowiska, Zasobów Naturalnych i Leśnictwa z dnia 5 listopada 1991 r. w sprawie klasyfikacji wód oraz warunków, jakim powinny odpowiadać ścieki wprowadzane do wód oraz do ziemi, Dz.U. Nr 116, poz. 503 ze zm.

50 Zob. § 6 pkt 4 rozporządzenia Rady Ministrów z dnia 27 grudnia 1993 r. w sprawie opłat za szczególne korzystanie z wód i urządzeń wodnych, Dz.U. Nr 133, poz. 637 ze zm.

51 Zob. zarządzenie Ministra Ochrony Środowiska Zasobów Naturalnych i Leśnictwa z dnia 7 lipca 1986 r. w sprawie rolniczego wykorzystania ścieków, M.P. Nr 23, poz. 170. 
padach $^{52}$, według którego przez ścieki rozumiano m.in. wody opadowe, ale tylko pochodzące $\mathrm{z}$ terenów zanieczyszczonych, $\mathrm{w}$ tym centrów miast, terenów przemysłowych, składowych, baz transportowych i dróg o dużym natężeniu ruchu wraz z parkingami. Do doprecyzowania pojęcia ścieków w kontekście wód opadowych doszło zaś jeszcze później - poprzez zmianę definicji ścieków obowiązującej w Prawie wodnym z 1974 r., na mocy art. 45 pkt 1 ustawy z dnia 27 lipca 2001 r. o wprowadzeniu ustawy - Prawo ochrony środowiska, ustawy o odpadach oraz zmianie niektórych ustaw ${ }^{53}$. Przyjęto wtedy definicję zgodną z przepisami ustawy z dnia 27 kwietnia 2001 r. Prawo ochrony środowiska ${ }^{54}$. W art. 3 pkt 38 ostatniej z ustaw za ścieki rozumiano wprowadzane do wód lub do ziemi wody opadowe lub roztopowe, ujęte $\mathrm{w}$ otwarte lub zamknięte systemy kanalizacyjne, pochodzące $\mathrm{z}$ powierzchni zanieczyszczonych o trwałej nawierzchni, w szczególności z miast, portów, lotnisk, terenów przemysłowych, handlowych, usługowych i składowych, baz transportowych, dróg i parkingów.

Odnosząc się do problemu wprowadzania wód opadowych do urządzeń kanalizacyjnych, trzeba zauważyć, że na mocy art. 142 Prawa wodnego z 1974 r. skreślone zostały przepisy art. 3 ust. 1 pkt 2 i ust. 2 oraz art. 7 i 8 ustawy o utrzymaniu czystości i porządku w miastach i osiedlach, co wynikało z poddania problematyki funkcjonowania urządzeń kanalizacyjnych i oczyszczalni ścieków miejskich oraz odprowadzania do nich nieczystości regulacjom art. 98-107 Prawa wodnego z 1974 r. Stąd też w definicji ścieków sprzed nowelizacji art. 18 ust. 1 pkt 1 Prawa wodnego z 1974 r. uwzględniano również wody zanieczyszczone wprowadzane do urządzeń kanalizacyjnych, czyli urządzeń służących do oczyszczania oraz odprowadzania ścieków w rozumieniu art. 98 ust. 2 cytowanej ustawy. Ustawa o utrzymaniu czystości i porządku w miastach i osiedlach została zresztą wkrótce w całości uchylona, zgodnie z art. 117 pkt 2 ustawy z dnia 31 stycznia 1980 r. o ochronie i kształtowaniu

52 Dz.U. Nr 96, poz. 592 ze zm.

53 Dz.U. Nr 100, poz. 1085 ze zm.

54 Tj. Dz.U. z 2013 r. poz. 1232 ze zm. 
środowiska ${ }^{55}$, zawierającej przepisy dotyczące utrzymania porządku i czystości w art. 57-58.

W szczególności, co do ścieków, ważne znaczenie miało wydane na podstawie art. 58 ustawy o ochronie i kształtowaniu środowiska rozporządzenie Rady Ministrów z dnia 30 września 1980 r. w sprawie ochrony środowiska przed odpadami i innymi zanieczyszczeniami oraz utrzymania czystości i porządku w miastach i wsiach ${ }^{56}$, albowiem to na jego podstawie terenowe organy administracji państwowej wykonywały zadania w zakresie budowy urządzeń kanalizacyjnych i komunalnych oczyszczalni ścieków oraz zapewnienia ich prawidłowej eksploatacji, a także określenia i zapewnienia wykonywania zadań przez komunalne przedsiębiorstwa (zakłady) oczyszczania ( $\S 2$ ust. 2 pkt 3). Ponadto, w myśl $\S 2$ ust. 3 pkt 1 tego rozporządzenia, mogły wprowadzić obowiązek podłączenia obiektów budowlanych na koszt właścicieli do komunalnej sieci kanalizacyjnej biegnącej wzdłuż ulicy, przy której były użytkowane obiekty. Przytoczone przepisy ustawy o ochronie i kształtowaniu środowiska utraciły moc, stosownie do art. 11 ustawy z dnia 13 września 1996 r. o utrzymaniu porządku i czystości w gminach ${ }^{57}$.

Urządzenia kanalizacyjne miast i wsi wykonywano na koszt budżetu państwa, za zwrotem części kosztów przez zainteresowanych właścicieli nieruchomości na terenach wsi, natomiast pozostałe na koszt zakładów (art. 99 ust. 1-4 Prawa wodnego z 1974 r.) $)^{58}$. Następnie, wobec zmian ustrojowych, jakie zaszły w Polsce po 1989 r., budowa urządzeń kanalizacyjnych, stosownie do art. 7 ust. 1 pkt 3 ustawy z dnia 8 marca 1990 r.

55 Dz.U. Nr 3, poz. 6 ze zm.

56 Dz.U. Nr 24, poz. 91 ze zm.

57 Tj. Dz.U. z 2013 r., poz. 1399 ze zm.

58 Przepis art. 99 ust. 1 Prawa wodnego z 1974 r. nie wyłączał stosowania przepisu art. 27 ust. 1 ustawy o gospodarce terenami w miastach i osiedlach, zgodnie z którym część kosztów wykonania urządzeń wodociągowych i kanalizacyjnych miast, odpowiadającą wzrostowi wartości nieruchomości powstałemu wskutek wykonania wymienionych urządzeń, pokrywali właściciele tych nieruchomości. Zob. uchwałę Sądu Najwyższego z dnia 29 kwietnia 1982 r. III AZP 1/82, publ. OSNC 1982/10/145. 
o samorządzie gminnym ${ }^{59}$, zaczęła stanowić zadanie własne gminy $^{60}$, a nowe zasady obejmujące współuczestniczenie mieszkańców miast $\mathrm{w}$ ich budowie określiły przepisy art. 1 pkt 6 ustawy z dnia 21 sierpnia 1997 r. o gospodarce nieruchomościami ${ }^{61}$. Oprócz tego, na właścicielach budynków w miastach ciążył w czasie ich budowy lub remontu obowiązek założenia wewnętrznej instalacji kanalizacyjnej i połączenia jej z przewodami sieci w ustalonym terminie (art. 101 Prawa wodnego z 1974 r.). Wprowadzanie ścieków do urządzeń kanalizacyjnych wymagało z kolei zezwolenia, a po nowelizacji ustawy ${ }^{62}-$ zawarcia umowy z właścicielem, lub wskazanym przez niego użytkownikiem tych urządzeń, i spełnienia ustalonych w akcie wykonawczym warunków wprowadzania ścieków (art. 102 ust. 1 i 2 Prawa wodnego z 1974 r.) ${ }^{63}$ oraz uiszczania stosownych opłat (art. 104 Prawa wodnego z 1974 r.) ${ }^{64}$. Do kosztów utrzymania i eksploatacji urządzeń kanalizacyjnych nie zaliczano jednak kosztów związanych z odprowadzaniem wód opadowych, zgodnie z $\S 3$ ust. 3 rozporządzenia Rady Ministrów z dnia 18 grudnia 1996 r. w sprawie urządzeń zaopatrzenia w wodę i urządzeń kanalizacyjnych oraz zasad ustalania opłat za wodę i wprowadzanie ścieków ${ }^{65}$.

59 Tj. Dz.U. z 2013 r., poz. 594 ze zm.

60 Odnośnie braku korespondencji pomiędzy wspomnianymi przepisami obu ustaw zob. A. Lipiński, Z problematyki zadań własnych gminy zwiazanych z zaspokajaniem zbiorowych potrzeb wspólnoty $w$ zakresie gospodarki wodnej, „Samorząd Terytorialny” 1997, nr 5, s. 23.

61 T. j. Dz.U. z 2010 r. Nr 102, poz. 651 ze zm.

62 Zob. art. 2 pkt 3 ustawy z dnia 27 kwietnia 1989 r. o zmianie ustawy o ochronie i kształtowaniu środowiska i ustawy - Prawo wodne, Dz.U. Nr 26, poz. 139, oraz art. 1 pkt 12 ustawy z dnia 27 kwietnia 1997 r. o zmianie ustawy - Prawo wodne, Dz.U. Nr 47, poz. 299.

63 Zob. rozporządzenie Rady Ministrów z dnia 19 maja 1999 r. w sprawie warunków wprowadzania ścieków do urządzeń kanalizacyjnych stanowiących mienie komunalne, Dz.U. Nr 50, poz. 501.

64 Szczegółowo dokonane zmiany w przepisach art. 98-107 Prawa wodnego z 1974 r. omawia: J. Rotko (red.), Prawo wodne z komentarzem, Wrocław 1999, s. 283-303.

${ }^{65}$ Dz.U. Nr 151, poz. 716 ze zm. 
Zagadnienia dotyczące wyposażenia obiektów budowlanych w urządzenia służące do odprowadzania wód opadowych określone zostały w wydanym na podstawie art. 6 ust. 2 pkt 1 ustawy z dnia 24 października 1974 r. Prawo budowlane ${ }^{66}$ rozporządzeniu Ministra Administracji, Gospodarki Terenowej i Ochrony Środowiska z dnia 3 lipca 1980 r. w sprawie warunków technicznych, jakim powinny odpowiadać budynki ${ }^{67}$. Zgodnie z $\S 13$ owego rozporządzenia, w wypadkach sytuowania bezpośrednio przy granicy działki budynków gospodarczych, wody opadowe z dachu od strony granicy działki nie mogły być odprowadzane na teren działki sąsiedniej. Odprowadzanie wód opadowych z terenu działki na teren sąsiedniej nieruchomości lub wzdłuż jej granicy w sposób niezabezpieczający tego terenu lub obiektu przed przenikaniem wód było zabronione, przy czym zakaz ten nie dotyczył naturalnego spływu wód opadowych (§ 79 ust. 1). Jeżeli budynek usytuowany był na terenach wyposażonych w sieć kanalizacji komunalnej, to obowiązywało podłączenie budynku do tej sieci i wyposażenie go w odpowiednią instalację kanalizacyjną oraz w razie konieczności urządzenie wstępnego oczyszczania ścieków (§ 74 ust. 1-2 Prawa budowlanego 1974 r.). Przewody spustowe do wewnętrznego odprowadzania wody opadowej z obiektów budowlanych miały spełniać wymagania określone dla pionów kanalizacji deszczowej i zostać zabezpieczone przed zanieczyszczeniem i zamarzaniem (§ 51), a dachy i tarasy oraz części budynku niezakryte, zagłębione w stosunku do otaczającego terenu (jak schody, pochylnie i studzienki piwniczne) powinny mieć urządzenia odprowadzające wody opadowe (§ 78).

Podobnie rozwiązania, dotyczące odprowadzania wód opadowych, przewidziano następnie $\mathrm{w}$ aktach wykonawczych do ustawy z dnia 7 lipca 1994 r. Prawo budowlane ${ }^{68}$, w myśl której obiekt budowlany, wraz ze związanymi z nim urządzeniami budowlanymi, należy projektować i budować w sposób określony w przepisach, w tym techniczno-budowlanych, oraz

67 Dz.U. Nr 17, poz. 62 ze zm.

68 Tj. Dz.U. z 2013 r., poz. 1409 ze zm. 
zgodnie z zasadami wiedzy technicznej, zapewniając m.in. spełnienie odpowiednich wymagań podstawowych związanych z ochroną środowiska oraz warunków użytkowych w zakresie usuwania ścieków i wody opadowej (art. 5 ust. 1 pkt 1 lit. d oraz pkt 2 lit. b). Sam projekt budowlany powinien natomiast zawierać oświadczenia właściwych jednostek organizacyjnych o zapewnieniu m.in. odbioru ścieków oraz odnośnie do warunków przyłączenia do sieci kanalizacyjnych (art. 34 ust. 3 pkt 3 Prawa budowlanego z 1994 r.).

Zgodnie z \& 28 rozporządzenia Ministra Gospodarki Przestrzennej i Budownictwa z 14 grudnia 1994 r. w sprawie warunków technicznych, jakim powinny odpowiadać budynki i ich usytuowanie ${ }^{69}$, niezbędne było wyposażenie działki budowlanej, na której sytuowano budynki, w odrębną kanalizację deszczową lub jej przyłączenie do kanalizacji ogólnospławnej. W razie zaś braku kanalizacji deszczowej lub ogólnospławnej dopuszczano odprowadzanie wód opadowych na własny teren. W myśl § 126 tego rozporządzenia, dachy i tarasy, a także zagłębienia wykonane przy ścianach zewnętrznych budynku (zejścia, zjazdy, fosy) powinny były mieć odprowadzenie wody opadowej do sieci kanalizacji ogólnospławnej, wyodrębnionej kanalizacji deszczowej, do dołów chłonnych lub na teren działki, a dachy ze spadkami do wewnątrz budynku miały mieć odwodnienie przy zastosowaniu wewnętrznych pionów, przyłączonych do sieci kanalizacji deszczowej lub ogólnospławnej. W przypadku zastosowania odrębnej sieci kanalizacji deszczowej wymagano też wprowadzenia do niej wód opadowych przewodami odrębnymi od przewodów odprowadzających ścieki bytowo-gospodarcze. Ukształtowanie terenu wokół budynku powinno było zapewniać swobodny spływ wody opadowej od budynku (§ 316 ust. 2), choć zabroniono jednocześnie dokonywania zmiany naturalnego spływu wód opadowych w celu kierowania go na teren nieruchomości sąsiedniej, bez zgody jej właściciela lub zarządcy $(\S 29)$. 


\section{WODY OPADOWE W OKRESIE OBOWIĄZYWANIA PRAWA WODNEGO Z $2001 \mathrm{R}$.}

Jak już wspomniałem we wstępie, wody opadowe mają zasadniczy wpływ na cyrkulację wody w przyrodzie. Z uwagi na to, że praktycznie zawsze zasilają one na lądzie wody powierzchniowe lub podziemne (pomijając część wód opadowych odparowujących z powrotem do atmosfery), rozważyć wypada, czy istnieje w ogóle potrzeba ich prawnego wyodrębnienia. Wydaje się, że kluczowe znaczenie ma kwestia czasowości istnienia tych wód. Nie budzi wątpliwości, iż wody opadowe mieszając się z wodami obecnymi na powierzchni oraz pod powierzchnią ziemi, przestają być samodzielnym bytem. Dochodzi jednak do tego albo natychmiast (np. z chwilą zetknięcia opadu bezpośrednio z lustrem jeziora), albo dopiero wtedy, kiedy stopniowo wsiąkną w glebę, przedostając się dalej aż do wód zgromadzonych w warstwie wodonośnej, bądź spłyną zagłębieniami terenu, natrafiając w końcu na brzegi cieków lub akwenów wodnych, chyba że zostaną wcześniej przejęte poprzez różnego rodzaju urządzenia techniczne, a następnie sztucznie odprowadzone za pomocą urządzeń wodnych (np. wylot, studnia chłonna). Siłą rzeczy istniejący stan prawny w zakresie gospodarowania wodami powinien uwzględniać specyfikę wód opadowych i skutki, jakie wywiera dla otoczenia ich pojawienie się oraz przemieszczanie, począwszy od momentu wystąpienia zjawiska opadu, a skończywszy na scaleniu wód z niego pochodzących z innymi wodami.

Podstawowym aktem prawnym we frapującej nas problematyce jest oczywiście Prawo wodne z 2001 r., które znajduje zastosowanie do wód śródlądowych oraz morskich wód wewnętrznych (art. 7 ust. 1). Wody śródlądowe na jego mocy dalej dzielą się, zgodnie ze znanym w hydrologii podziałem, na wody powierzchniowe i wody podziemne (art. 5 ust. 1), choć jego kryteria są nieco inne niż $\mathrm{w}$ nauce o wodzie $^{70}$. Nie zostały przy

70 Zob. M. Marszelewski, W. Marszelewski, Problemy własności jezior w Polsce, „Przegląd Prawa Ochrony Środowiska” 2013, nr 3, s. 32. 
tym prawnie zdefiniowane wody powierzchniowe, w odróżnieniu od wód podziemnych, przez które rozumie się wszystkie wody znajdujące się pod powierzchnią ziemi w strefie nasycenia (w tym wody gruntowe pozostające w bezpośredniej styczności z gruntem lub podglebiem), stosownie do art. 9 ust. 1 pkt 22 Prawa wodnego z 2001 r. Skądinąd w doktrynie podnosi się, że jest to zrozumiałe, gdyż w świetle art. 5 ust. 1 Prawa wodnego z 2001 r. każda woda, która nie jest wodą podziemną, jest wodą powierzchniową ${ }^{71}$. Jednakowoż w art. 5 ust. 3 pkt 1 i 2 Prawa wodnego z 2001 r. dokonano wyłącznie dychotomicznego podziału wód powierzchniowych na wody płynące (w ciekach naturalnych, kanałach oraz w źródłach, z których cieki biorą początek, znajdujące się w jeziorach oraz innych naturalnych zbiornikach wodnych o ciągłym bądź okresowym naturalnym dopływie lub odpływie wód powierzchniowych, a także znajdujące się w sztucznych zbiornikach usytuowanych na wodach płynących) oraz stojące (znajdujące się w jeziorach oraz innych naturalnych zbiornikach wodnych niezwiązanych bezpośrednio, w sposób naturalny, z powierzchniowymi wodami płynącymi), pomijając całkowicie umiejscowienie wód opadowych w podanej systematyce. Nadto przepisy o wodach stojących mają odpowiednio zastosowanie tylko do wód znajdujących się w zagłębieniach terenu powstałych w wyniku działalności człowieka, niebędących stawami (art. 5 ust. 4 Prawa wodnego z 2001 r.).

Nasuwa się zatem nieodparcie pytanie, czy w przytoczonej klasyfikacji mieszczą się wody opadowe, a jeśli tak, to do jakiej kategorii wód przynależą. W konsekwencji, kto jest ich właścicielem, jakie są jego uprawnienia oraz jakie na nim z tego tytułu spoczywają obowiązki. Odpowiedź na postawione pytanie wcale nie jest prosta. W celu jej udzielenia konieczne wydaje się sięgnięcie po istniejące reguły wykładni prawa. Przede wszystkim historycznej, które pozwalają podczas przeprowadzania interpretacji na wzięcie pod uwagę argumentów wynikających z historycznego kontekstu i ewolucji norm prawnych, a także, wywodzącego się z wykładni systemowej, zakazu interpretowa-

71 J. Rotko (red.), Prawo wodne. Komentarz, Wrocław 2002, s. 22. 
nia przepisów prawa w sposób prowadzący do ich sprzeczności $\mathrm{z}$ innymi przepisami ${ }^{72}$.

W kwestii statusu wód opadowych musimy uwzględnić, że już ustawa wodna z 1922 r. zawierała regulacje dotyczące problematyki własności wód opadowych (art. 4 lit. a i b) oraz ich użytkowania (art. 36 ust. 1 i 2), wraz z wprowadzeniem pewnych ograniczeń $\mathrm{w}$ tej materii. Przyjęte przed ponad dziewięćdziesięciu laty przepisy, chroniące przed szkodliwym oddziaływaniem, związanym ze zmianami w naturalnym spływie wód na grunty przyległe, niewątpliwie odnosiły się do wód opadowych, co wynikało z literalnego brzmienia art. 17 ust. 1-4 ustawy wodnej, w odróżnieniu od następnych aktów prawnych.

W późniejszym okresie, w Prawie wodnym z 1962 r., doszło do pewnego wyłomu, dość istotnego z dalszej perspektywy. Dokonując mianowicie podziału wód śródlądowych, nie wymieniono bezpośrednio wód opadowych. O ich zaliczeniu do tychże wód decydowała za to odpowiednia interpretacja art. 7 pkt 1 in fine. Pozwalała ona na zaklasyfikowanie do wód powierzchniowych wód opadowych, które pomimo znajdowania się na powierzchni ziemi, zostały potraktowane odrębnie i nie wyszczególniono ich w dalszym podziale wód powierzchniowych (art. 8 pkt 1). W efekcie do wód opadowych miały zastosowanie przepisy o zwykłym korzystaniu z wód, w tym art. 38 Prawa wodnego z $1962 \mathrm{r}$. w przedmiocie zmiany stanu wody na gruncie. Z kolei Prawo wodne z 1974 r. całkowicie pomijało wody opadowe przy klasyfikowaniu wód śródlądowych. Nie miało w tym kontekście większego znaczenia traktowanie wód opadowych jako części składowej gruntu, wedle art. 47 § 2 k.c. Dalej idące konsekwencje wynikały bowiem z braku możliwości objęcia wód opadowych przepisem szczególnym, tj. art. 143 zd. drugie k.c., z uwagi na nieuwzględnienie ich w art. 7 ust. 1 Prawa wodnego z 1974 r., co wskazywało na wyłączenie stosowania do wód opadowych nie tylko przepisów o zmianie stanu wody na gruncie, ale również pozostałych uregulowań tej ustawy. Takie podejście wydaje się o tyle nieuzasadnione, iż tak

72 Zob. L. Morawski, Zasady wykładni prawa, Toruń 2006, s. 129-130, 153. 
naprawdę art. 50 cytowanej ustawy nie odbiegał znacząco od art. 17 Prawa wodnego z 1922 r., którego celem było przecież powstrzymanie negatywnego oddziaływania na działki sąsiednie, powstałego najczęściej poprzez niewłaściwe skierowanie wód opadowych. Niemniej Sąd Najwyższy w wyroku z dnia 29 sierpnia $2001 \mathrm{r}^{73}$ stwierdził, że przepis art. 50 ust. 1 Prawa wodnego z 1974 r. nie miał zastosowania do wód opadowych, lecz do wód podlegających reżimowi zwykłego korzystania z wód, czyli wody stanowiącej własność właścicieli gruntu oraz wody podziemnej, wobec czego także odprowadzanie rynnami wody opadowej z dachu wznoszonego budynku w kierunku nieruchomości sąsiedniej podlegało ocenie wyłącznie na podstawie przepisów Prawa budowlanego, stanowiąc naruszenie warunków technicznych (§ 29 i $\S 126$ ust. 1 i 3 rozporządzenia Ministra Gospodarki Przestrzennej i Budownictwa z 1994 r. w sprawie warunków technicznych, jakim powinny odpowiadać budynki i ich usytuowanie).

Trudno ustalić z całą pewnością, ale właśnie trwający spór, zakończony powyższym wyrokiem, legł najprawdopodobniej u podstaw dokonanych zmian legislacyjnych, powodujących, że w Prawie wodnym z 2001 r. wody opadowe znów zostały literalnie wymienione. Niestety, jedynie w art. 29 ust 1 cytowanej ustawy, gdzie jako jeden z przykładów zmiany stanu wody na gruncie egzemplifikowano zmianę kierunku odpływu wody opadowej ze szkodą dla gruntów sąsiednich. Jest to w mojej ocenie spore niedopatrzenie ze strony ustawodawcy, skutkujące powstaniem pozornej sprzeczności pomiędzy owym przepisem a art. 5 ust. 3 Prawa wodnego z 2001 r. Z tego ostatniego wszelako nie wynika bezpośrednio, że ustawa znajduje zastosowanie do wód opadowych, ale trzeba przyjąć, w celu usunięcia pojawiających się dwuznaczności, iż wody opadowe przynależą do wód śródlądowych. Ze względu natomiast na ich silne związanie z nieruchomościami gruntowymi, posiadają charakterystyczne cechy wód stojących, stanowiących w odróżnieniu od wód płynących własność właściciela gruntu (art. 12 ust. 1 Prawa wodnego z 2001 r.). 
Wobec powyższego nie może dziwić, że w trakcie omawiania praw i obowiązków związanych z występowaniem wód opadowych, będą przeważały te z nich, które od strony podmiotowej dotyczą osoby właściciela gruntu stykającego się z owymi wodami, a od strony przedmiotowej sięgają problematyki korzystania przez niego ze wspomnianych wód, tj. ujmowania oraz odprowadzania, a także dalszych konsekwencji w postaci konieczności powstrzymywania się od zmian stanu wody na gruncie powodujących szkody dla gruntów sąsiednich, wymogu posiadania pozwolenia wodnoprawnego, uiszczania opłat czy też ponoszenia przewidzianych sankcji za naruszenie zawartych w przepisach dyspozycji. Chociaż przedstawione zostaną również pokrótce zadania, co do odprowadzania wód opadowych, realizowane przez gminy, przedsiębiorstwa wodociągowo-kanalizacyjne, czy też spoczywające na projektantach obiektów budowlanych.

Otóż właściciel gruntu może swobodnie używać wód znajdujących się na jego nieruchomości celem zaspokojenia potrzeb własnego gospodarstwa domowego oraz gospodarstwa rolnego, w ramach zwykłego korzystania ze swoich wód, odbywającego się bez potrzeby posiadania pozwolenia wodnoprawnego (art. 36 ust. 2 Prawa wodnego z 2001 r.). Nieliczne wyjątki odnoszą się wyłącznie do nawadniania gruntu lub upraw wodą podziemną za pomocą deszczowni, poboru wody i odprowadzania ścieków, rolniczego wykorzystania ścieków w ilości większej niż $5 \mathrm{~m}^{3}$ oraz poboru wody na potrzeby działalności gospodarczej. Zgodnie z art. 29 ust. 1 Prawa wodnego z 2001 r. właściciel gruntu nie może jednak zmieniać stanu wody na grun$\mathrm{cie}^{74}$ (o ile przepisy ustawy nie stanowią inaczej), a zwłaszcza ${ }^{75}$

74 Przez stan wody na gruncie należy rozumieć zarówno naturalny stan wody na gruncie, jak i stan wody na gruncie, który powstał w wyniku legalnego zagospodarowania terenu. Zob. wyrok Naczelnego Sądu Administracyjnego z dnia 25 lipca 2012 r. - II OSK 799/11, publ. System Informacji Prawnej LEX nr 1252189.

75 Użycie przez ustawodawcę słowa „a zwłaszcza” pozwala na stwierdzenie, że w zakresie ustawowego pojęcia „zmiana stanu wody na gruncie” mieści się również zmiana kierunku odpływu z określonej działki wody opadowej. Taka zmiana może być również spowodowana tym, że właściciel gruntu pod- 
kierunku odpływu znajdującej się na jego gruncie wody opadowej ani kierunku odpływu ze źródeł - ze szkodą dla gruntów sąsiednich ${ }^{76}$, a ponadto odprowadzać wód oraz ścieków na grunty sąsiednie ${ }^{77}$. W myśl ust. 2 cytowanego artykułu, na właścicielu gruntu ciąży też obowiązek usunięcia przeszkód oraz zmian w odpływie wody, powstałych na jego gruncie wskutek przypadku lub działania osób trzecich, ze szkodą dla gruntów sąsiednich. Wójt (burmistrz lub prezydent miasta) jest władny wtedy nakazać w drodze decyzji przywrócenie stanu poprzedniego, albo wykonanie urządzeń zapobiegających szkodom ${ }^{78}$

wyższy poziom swojej działki, na przykład poprzez nawiezienie na nią ziemi. Zob. wyrok Wojewódzkiego Sądu Administracyjnego w Warszawie z dnia 7 marca 2007 r. - IV SA/Wa 254/07, publ. System Informacji Prawnej LEX nr 339427.

76 Przy czym przepis ów nie ma charakteru prewencyjnego w tym sensie, że nie służy zabezpieczeniu przed hipotetyczną szkodą. Zob. wyrok Wojewódzkiego Sądu Administracyjnego w Gliwicach z dnia 30 listopada 2011 r. II SA/Gl 411/11, publ. System Informacji Prawnej LEX nr 1152534. Jeśli jednak już do szkody dojdzie, to między nią, a zmianą stanu wody na gruncie, musi istnieć związek przyczynowo-skutkowy. Zob. wyrok Wojewódzkiego Sądu Administracyjnego w Krakowie z dnia 25 października 2012 r. - II SA/Kr 420/12, publ. System Informacji Prawnej LEX nr 1235517, a także wyrok Wojewódzkiego Sądu Administracyjnego w Szczecinie z dnia 4 kwietnia 2012 r. II SA/Sz 1381/11, publ. System Informacji Prawnej LEX nr 1138839 oraz wyrok Wojewódzkiego Sądu Administracyjnego w Poznaniu z dnia 3 kwietnia 2012 r. - II SA/Po 1034/11, publ. System Informacji Prawnej LEX nr 1145850.

77 Zmianą stanu wody na gruncie jest zarówno działanie powodujące zwiększenie jej objętości na gruncie, jak i zmniejszenie. Taką zmianą nie będzie zatem zmiana stanu wód podziemnych, o ile nie wpływa ona na zmianę ilości wody na gruncie. Zmianą stanu wody na gruncie jest więc każde działanie, którego efektem jest zmiana ilościowa wody oraz zmiana w zakresie jej przepływu przez grunt. Zob. M. Wincenciak, Zmiana stanu wody na gruncie. Analiza prawna art. 29 ustawy Prawo wodne, „Prawo i Środowisko” 2005, nr 4, s. 130.

78 Konstrukcja przepisu pozwala przyjąć taką regułę interpretacyjną, iż przywrócenie stanu pierwotnego jest środkiem subsydiarnym, który należy zastosować, kiedy nie ma możliwości wykonania urządzeń zapobiegających szkodom, albo, gdy z okoliczności sprawy wynika, że ich wykonanie nie zapobiegnie szkodliwym wpływom na grunt sąsiedni. Zob. decyzję Samorządowego Kolegium Odwoławczego w Krakowie z dnia 24 lutego 2006 r. - Kol. Odw. 4281/05/Oś, publ. OwSS 2006/3/73. 
(art. 29 ust. 3 Prawa wodnego) ${ }^{79}$, ale już nie jest kompetentny do rozstrzygnięcia $\mathrm{w}$ przedmiocie odszkodowania ${ }^{80}$. Podobnie nie przewiduje się w obecnym stanie prawnym wydawania decyzji o polepszeniu stosunków wodnych na gruncie. Właściciele przyległych gruntów mogą wszakże w drodze pisemnej ugody ustalić zmiany stanu wody na gruntach, jeżeli zmiany te nie wpływają szkodliwie na inne nieruchomości lub na gospodarkę wodną (art. 30 ust. 1 Prawa wodnego z 2001 r.) i nie zostały spowodowane wprowadzaniem ścieków do wód lub do ziemi. Ich realizacja wymaga zatwierdzenia $\mathrm{w}$ drodze decyzji administracyjnej, wydanej przez wójta (burmistrza, prezydenta miasta), stosownie do art. 30 ust. 2 Prawa wodnego z 2001 r.

W istocie zatem art. 29 Prawa wodnego z 2001 r. stanowi rozwinięcie wcześniej obowiązujących przepisów art. 50 ustawy z 1974 r., zawierających zakaz zmiany stanu wody na gruncie, w ramach zwykłego korzystania z wód. Obecnie literalnie wyszczególniono nieograniczony czasowo zakaz zmiany kierunku odpływu wody opadowej i odpływu ze źródeł, jeśli taka zmiana mogłaby być szkodliwa dla gruntów sąsiednich, a tak-

79 Tak więc mamy bez wątpienia nadal do czynienia $\mathrm{z}$ administracyjnym trybem orzekania o przywróceniu stanu poprzedniego lub wykonaniu urządzeń zapobiegających szkodom na gruntach sąsiednich. Zob. T. Judecki, Związany charakter decyzji o przywróceniu stanu poprzedniego lub wykonaniu urządzeń zapobiegających szkodom na gruntach sq̨iednich na skutek dokonanej przez właściciela gruntów zmiany stanu wód na gruncie, „Nowe Zeszyty Samorządowe" 2011, nr 6, s. 22. Na trudności wynikające z przeprowadzania w toku takich postępowań ekspertyz hydrologicznych, które znacznie obciążają budżety gmin, zwraca uwagę A. Odrzywolska, Potrzebna korekta przepisów, „Przegląd Komunalny” 2012, nr 5, s. 56-57.

80 Sprawy o ochronę własności są sprawami cywilnymi. W sprawach cywilnych zasadą jest dopuszczalność drogi sądowej, z wyjątkami wynikającymi z przepisów szczególnych, w tym m.in. art. 29 ust. 3 Prawa wodnego z 2001 r., który przewiduje administracyjny tryb postępowania dla rozstrzygnięcia sporu. Ze względu na wyjątkowy charakter przepis ten nie może być traktowany rozszerzająco. Oznacza to, że jeżeli roszczenie negatoryjne o przywrócenie stanu zgodnego z prawem przybiera inną postać niż żądanie przywrócenia stanu poprzedniego lub wykonania urządzeń zapobiegających szkodom, to takie roszczenie powinno być dochodzone w postępowaniu sądowym. Zob. uchwałę Sądu Najwyższego z dnia 27 czerwca 2007 r. - III CZP 39/07, publ. OSNC 2008/7-8/85. 
że bezwzględny zakaz odprowadzania wód i ścieków na grunty sąsiednie. Nie jest on bowiem uzależniony od tego, czy na nieruchomościach sąsiednich wystąpi szkoda, czy też nie ${ }^{81}$. Zamieszczenie art. 29 poza rozdziałem odnoszącym się do zwykłego korzystania z wody ma z kolei na celu usunięcie wątpliwości, czy przepis ten dotyczy wszelkich zmian ${ }^{82}$. Właściciel powinien mieć w rezultacie pełną kontrolę nad szkodliwymi zdarzeniami na jego gruncie, niezależnie od tego, z jakiej przyczyny zostały one spowodowane, co według przyjmowanego w literaturze poglądu rozszerza katalog obowiązków właściciela nieruchomości w sferze stanu wód poza zakres obowiązków wynikających z prawa cywilnego ${ }^{83}$. Stanowi wszak źródło nie tylko określonych zakazów, lecz także nakazu zapewnienia odpowiedniego stanu gruntu w zakresie stosunków wodnych ${ }^{84}$.

Wprawdzie właściciel wód opadowych jest uprawniony zagospodarowywać wody opadowe na swojej działce w sposób nieskutkujący dokonaniem szkodliwej zmiany stanu wody na gruncie i skierowaniem odpływu na grunty sąsiednie oraz pozbyciem się ich nadmiaru poprzez odprowadzenie na grunty sąsiednie, ale nie oznacza to w żadnej mierze, że powinien zatrzymać w całości lub w części na swej nieruchomości wszystkie wody opadowe, jakie na niej się znajdą. Dopuszczalne są bowiem dwa różne rozwiązania, w zależności od miejsca występowania wód opadowych. Polegają one albo na odprowadzeniu nadwyżki wód opadowych do wód powierzchniowych (tam gdzie brak jest urządzeń kanalizacyjnych bądź możliwości przejęcia przez te urządzenia wód opadowych), albo na wprowadzeniu do istniejących urządzeń kanalizacyjnych, jakkolwiek kryteria konieczne do spełnienia w podanym zakresie są odmienne, kiedy lokalizacja wód opadowych pozwala na ich jednoczesne zaklasyfikowanie jako ścieki.

81 Zob. B. Rakoczy (red.), Prawo wodne. Komentarz, Warszawa 2013, s. 160.

82 Zob. I. Koza, L. Osuch-Chacińska, M. Pełda-Sypuła, M. Rytlewski, Nowe prawo wodne, Zielona Góra 2002, s. 28-29.

83 J. Szachułowicz, Prawo wodne. Komentarz, Warszawa 2010, s. 120.

84 Zob. M. Kałużny, Prawo wodne. Komentarz, Warszawa 2012, s. 129. 
Jeśli chodzi o odprowadzanie przez właściciela gruntów jego wód opadowych do wód powierzchniowych, to trzeba dostrzec, że zgodnie z art. 122 ust. 1 pkt 1 w zw. z art. 37 pkt 1 i 2 Prawa wodnego z 2001 r. szczególnym korzystaniem z wód jest teraz nie tylko pobór wód oraz wprowadzanie ścieków do wód lub do ziemi, ale także odprowadzanie wód powierzchniowych $^{85}$, co potwierdza przepis art. 9 ust. 1 pkt 19 lit. f tej ustawy, według którego urządzeniami wodnymi są m.in. wyloty urządzeń służących do wprowadzania wody do wód. Wydaje się więc nie mieć wpływu na istniejący wymóg posiadania pozwolenia wodnoprawnego, czy mamy do czynienia z wodami opadowymi czystymi, czy też z zanieczyszczonymi, za które przyjęto, tak jak poprzednio, wprowadzane do wód lub do ziemi wody opadowe lub roztopowe ${ }^{86}$, ujęte $\mathrm{w}$ otwarte lub zamknięte systemy kanalizacyjne $^{87}$, pochodzące z powierzchni zanieczyszczonej o trwałej nawierzchni, w szczególności z miast, portów lotnisk, terenów przemysłowych, handlowych, usługowych i składowych, baz transportowych oraz dróg i parkingów (art. 9 ust. 1 pkt 14 lit. c Prawa wodnego z 2001 r. $)^{88}$. Wyjątek stanowi wprowadzanie

85 Przepisy dotyczące odwadniania nie mogą już w żadnej mierze znajdować zastosowania do odprowadzania wód opadowych, gdyż w świetle art. 124 pkt 6 Prawa wodnego odnoszą się wyłącznie do wód podziemnych.

86 Udzielenie pozwolenia wodnoprawnego na odprowadzanie wód opadowych jest jednoznaczne z udzieleniem tego pozwolenia również na odprowadzanie wód roztopowych, gdyż nie ma możliwości realnego ich rozdzielenia. Zob. wyrok Wojewódzkiego Sądu Administracyjnego w Gdańsku z dnia 16 czerwca 2011 r. - II SA/Gd 272/11, publ. System Informacji Prawnej LEX nr 950539.

87 W kwestii wymiarowania kanalizacji zob. A. Kotowski, O potrzebie dostosowania zasad wymiarowania kanalizacji $w$ Polsce do wymagań normy PN-EN 752 i zaleceń Europejskiego Komitetu Normalizacji, „Gaz, Woda i Technika Sanitarna" 2006, nr 6, s. 20-26.

88 Na znaczącą ilość substancji szkodliwych zawartych w wodach opadowych pochodzących z odwadniania dróg o dużym natężeniu ruchu zwracają uwagę M. Niemiec, B. Wiśniowska-Kielian, Zanieczyszczenie metalami ciężkimi wód spływających z dróg pobranych ze zbiorników odparowujących, „Inżynieria Ekologiczna" 2008, nr 20, s. 57-63. Ponadto zob. A. Nowakowska-Błaszczyk, P. Błaszczyk, Wpływ odprowadzania wód deszczowych z terenów zurbanizowanych na osiągnięcie dobrego stanu ekologicznego wód powierzchniowych, „Gaz, Woda i Technika Sanitarna" 2011, nr 7-8, s. 254-259. 
bez pozwolenia wodnoprawnego do własnych wód stojących lub do ziemi, w ramach zwykłego korzystania z wód, oczyszczonych wód opadowych z terenów zanieczyszczonych w ilości do $5 \mathrm{~m}^{3}$ na dobę (art. 36 ust 3 pkt 4 Prawa wodnego z 2001 r.) oraz odprowadzanie do ziemi w każdej ilości wód z połaci dachowych, które niezależnie od faktycznych parametrów wody nie powinny być traktowane jako ścieki, gdyż dachy nie są rodzajem nawierzchni, a odprowadzanie czystych wód do ziemi wcale nie zostało zaklasyfikowane w art. 31 ust. 1-5 Prawa wodnego jako korzystanie z wód albo inna czynność, do której mają zastosowanie przepisy o korzystaniu z wód. Wody opadowe z dachu można zresztą również swobodnie pozyskiwać poprzez system rynien i spustów, a następnie magazynować i wykorzystywać dalej wedle własnego uznania, co wynika z art. 8 ust 2 Prawa wodnego z 2001 r., w myśl którego przepisów ustawy nie stosuje się do korzystania z wód zgromadzonych za pomocą urządzeń oraz instalacji technicznych niebędących urządzeniami wodnymi. Pozwolenie wodnoprawne nie jest też wymagane na odprowadzanie wszelkich wód z wykopów budowlanych, w ramach szczególnego korzystania z wód, stosownie do art. 124 pkt 9 wspomnianej ustawy. Należy jednak pamiętać, że przepisy dotyczące korzystania z wód stosuje się też odpowiednio do użytkowania wód znajdujących się w rowach (art. 31 ust. 4 pkt 3 Prawa wodnego), czyli urządzeniach wodnych (art. 9 ust. 1 pkt 19 lit. a cytowanej ustawy), powodując, iż odprowadzanie do nich wód opadowych jest dopuszczalne, lecz zawsze wymaga pozwolenia wodnoprawnego (jeżeli oczywiście rowy te nie stanowią jednocześnie własności właściciela wód opadowych a ilość odprowadzanej wody nie przekracza $5 \mathrm{~m}^{3}$ na dobę) ${ }^{89}$. Wydaje się to rozwiązaniem zasadnym. Co do wód opadowych,

89 Pomijam w tym miejscu kwestię, że nie każdy rów jest urządzeniem wodnym. Rowy szczelne, wyizolowane ze środowiska, nie kształtują zasobów wodnych i są traktowane jako otwarte systemy kanalizacyjne. Zob. W. Rejman, Stup powietrza oblany żelazem czyli o przepustach, rowach $i$ aspektach prawnych uwag i wniosków kilka, „Gospodarka Wodna” 2013, nr 8, s. 297-302; L. Osuch-Chacińska, Komentarz do artykułu „Stup powietrza oblany żelazem czyli o przepustach, rowach $i$ aspektach prawnych uwag $i$ wniosków kilka", „Gospodarka Wodna” 2013, nr 10, s. 401-402. 
dokonanie technicznej oceny możliwości ich odprowadzania jest wszak konieczne ${ }^{90}$, gdyż zwiększenie w ten sposób ilości wody odprowadzanej zwłaszcza rowami i szybkości jej spływu (tereny utwardzone, odprowadzanie wody z rynien) może niejednokrotnie skutkować zalewaniem gruntów przyległych oraz potrzebą przebudowy urządzeń idącą w kierunku zwiększenia przepustowości, albo nawet zastosowaniem innych rozwiązań, np. w postaci zmiany trasy ${ }^{91}$. Kiedy jednak doszłoby do powstania szkody w wyniku działalności zgodnej z pozwoleniem wodnoprawnym, wtedy do ich naprawienia stosuje się przepisy art. 186 Prawa wodnego. Odprowadzanie wód opadowych bez pozwolenia wodnoprawnego stanowi natomiast wykroczenie z art. 192 ust. 1 Prawa wodnego, podobnie jak naruszenie warunków przyznanego uprawnienia, które może zostać wówczas cofnięte lub ograniczone (art. 136 ust. 1 pkt 1 Prawa wodnego), a za ewentualną szkodę korzystający z wód odpowiada na zasadach ogólnych k.c.

Przyjęcie przez ustawodawcę pewnej fikcji prawnej, poprzez zrównanie niektórych kategorii wód opadowych z zaliczonymi do ścieków wodami zużytymi, powoduje konieczność spełnienia warunków określonych dla pozwolenia wodnoprawnego

90 Warto w tym miejscu zwrócić uwagę na najnowsze metody zarządzania wodami deszczowymi. Zob. M. Barszcz, Innowacyjne metody zarzadzania wodami deszczowymi w obszarach zurbanizowanych, „Gaz, Woda i Technika Sanitarna” 2013, nr 1, s. 12; A. Kocewiak, Nowoczesne sposoby zagospodarowania wody deszczowej, [w:] J. Łomotowski (red.), Wody opadowe a zjawiska ekstremalne. Materiaty konferencyjne z konferencji naukowo-technicznej „Zjawiska ekstremalne $w$ eksploatacji infrastruktury komunalnej" 1-2.02.2011, Warszawa 2011, s. 231; G. Sakson, Wykorzystanie wód opadowych $w$ budynkach, „Rynek Instalacyjny" 2010, nr 5, s. 50-53; E. Burszta-Adamiak, A. Sylwester, Projektowanie dachów zielonych, „Rynek Instalacyjny” 2010, nr 12, s. 81-83. Należy ponadto wskazać na istotną rolę retencji terenowej w ograniczaniu spływów powierzchniowych. Zob. W. Dąbrowski, Rola retencji terenowej w ograniczaniu spływów powierzchniowych na przykładzie pola golfowego, „Gaz, Woda i Technika Sanitarna" 2007, nr 12, s. 17-21; E. Burszta-Adamiak, Zagospodarowanie spływów opadowych za pomoca systemów bioretencji, „Rynek Instalacyjny” 2011, nr 3, s. 91-93.

91 Zob. L. Osuch-Chacińska, Przykłady z orzecznictwa, „Gospodarka Wodna" 2010, nr 10, s. 397. 
na wprowadzanie ścieków do wód ${ }^{92}$, choć odstąpiono od części rygorów obowiązujących generalnie w tej materii. Dopuszczalne jest mianowicie wprowadzanie wód opadowych lub roztopowych oraz wód z przelewów kanalizacji deszczowej do wód powierzchniowych lub do ziemi, nawet w odległości mniejszej niż 1 kilometr od granic kąpielisk i plaż publicznych nad wodami. Wody opadowe lub roztopowe można także odprowadzać do jezior i ich dopływów. Zabronione jest jednak wprowadzanie ścieków bezpośrednio do wód podziemnych (art. 39 ust. 1 pkt 1 Prawa wodnego z 2001 r.). Z kolei zanieczyszczone wody opadowe, wprowadzane do wód lub do ziemi w ramach zwykłego albo szczególnego korzystania z wód, powinny być zgodnie z art. 41 ust. 1 Prawa wodnego z 2001 r. oczyszczone w stopniu wymaganym przepisami ustawy, ale w pewnych sytuacjach (wyszczególnionych w ust. 5 i 6 cytowanego artykułu) organ właściwy do wydania pozwolenia wodnoprawnego, którym co do zasady jest starosta ${ }^{93}$, może określić w pozwoleniu wodnoprawnym wartości zanieczyszczeń zarówno niższe, jak i wyższe od dopuszczalnych. Zanieczyszczone wody opadowe mogą być także wykorzystywane rolniczo, w myśl art. 44 ust. 1-4 Prawa wodnego z 2001 r. $^{94}$

Wprowadzanie do wód lub do ziemi zanieczyszczonych wód opadowych w ramach szczególnego korzystania z wód wymaga uiszczenia niezbędnej opłaty. Podmiot korzystający ze środowiska ustala we własnym zakresie wysokość należnej z tego tytułu opłaty ${ }^{95}$ i wnosi ją na rachunek właściwego urzędu mar-

92 Systemy ich podczyszczania są zależne m.in. od parametrów fizycznych zawiesin wód deszczowych. Zob. W. Dąbrowski, Parametry fizyczne zawiesin wód deszczowych jako podstawa do projektowania systemów podczyszczania, „Gaz, Woda i Technika Sanitarna” 2001, nr 6, s. 221-224.

93 W wymienionych w art. 140 ust. 2 i 2a Prawa wodnego z 2001 r. przypadkach organem tym może być również właściwy marszałek województwa, albo dyrektor regionalnego zarządu gospodarki wodnej.

94 Zob. rozporządzenie Ministra Środowiska z dnia 24 lipca 2006 r. w sprawie warunków, jakie należy spełnić przy wprowadzaniu ścieków do wód lub do ziemi, oraz w sprawie substancji szczególnie szkodliwych dla środowiska wodnego, Dz.U. Nr 137, poz. 984 ze zm.

95 Jednostkowe stawki opłat za powierzchnie zanieczyszczone o trwałej nawierzchni, z których są wprowadzane do wód lub do ziemi wody opadowe 
szałkowskiego, stosownie do art. 284 ustawy z dnia 27 kwietnia 2001 r. Prawo ochrony środowiska. Jeśli ścieki opadowe lub roztopowe stanowią mieszaninę z innymi ściekami, ujmowaną kanalizacją ogólnospławną i odprowadzaną wylotem, to opłata uzależniona jest od rodzaju i ilości substancji w niej zawartych, kiedy natomiast dochodzi do odprowadzania zanieczyszczonych wód opadowych wylotem z kanalizacji deszczowej, zależy ona od wielkości, rodzaju i sposobu zagospodarowania terenu. Dla wykonania nałożonego z mocy ustawy obowiązku niezbędne jest przedłożenie marszałkowi województwa wykazów zawierających informacje i dane niezbędne do ustalenia wysokości opłat, których wzór określono w akcie wykonawczym (art. 286 ust. 1 i 3 Prawa ochrony środowiska) ${ }^{96}$. W razie wprowadzania ścieków do wód lub do ziemi bez wymaganego pozwolenia na podmiocie korzystającym ze środowiska ciąży obowiązek poniesienia opłaty podwyższonej ${ }^{97}$, natomiast naruszenie warunków określonych w pozwoleniach skutkuje nałożeniem administracyjnej kary pieniężnej, o której mowa w art. 298 ust. 1 pkt 2 Prawa ochrony środowiska.

Jeżeli podmiot korzystający ze środowiska ${ }^{98}$ negatywnie oddziałuje na środowisko, to starosta może w drodze decyzji nałożyć obowiązek ograniczenia oddziaływania na środowisko i jego zagrożenia lub przywrócenia środowiska do stanu

lub roztopowe, ujęte w otwarte lub zamknięte systemy kanalizacyjne, z wyjątkiem kanalizacji ogólnospławnej, zostały określone w § 5 rozporządzenia Rady Ministrów z dnia 14 października 2008 r. w sprawie opłat za korzystanie ze środowiska, Dz.U. Nr 196, poz. 1217 ze zm. Podlegają one aktualizacji, a ich wysokość na dany rok jest ogłaszana w drodze obwieszczenia. Obecnie obowiązuje obwieszczenie Ministra Środowiska z dnia 13 sierpnia $2013 \mathrm{r}$. w sprawie wysokości stawek opłat za korzystanie ze środowiska na rok 2014, M.P. poz. 729.

96 Wprowadzający ścieki do wód lub do ziemi sporządza wykazy zgodne ze wzorami, o których mowa w § 2 i 5 rozporządzenia Ministra Środowiska z dnia 18 czerwca 2009 r. w sprawie wzorów wykazów zawierających informacje i dane o zakresie korzystania ze środowiska oraz o wysokości należnych opłat, Dz.U. Nr 97, poz. 816.

97 Zob. art. 292 pkt 2 Prawa ochrony środowiska.

98 Definicję podmiotu korzystającego ze środowiska zawiera art. 3 pkt 20 Prawa ochrony środowiska. 
właściwego. Podobnie wójt (burmistrz, prezydent miasta) jest władny do nakazania osobie fizycznej, której działalność negatywnie oddziałuje na środowisko, wykonanie w określonym czasie czynności zmierzających do ograniczenia negatywnego oddziaływania (art. 362 i 363 cytowanej ustawy). Stosowny obowiązek może zatem zostać nałożony w zasadzie w każdym stanie faktycznym. Nawet wtedy, kiedy potencjalna uciążliwość nie została spowodowana działalnością wymagającą posiadania pozwolenia ${ }^{99}$. Wyjątek wynika $\mathrm{z}$ art. 7a Prawa ochrony środowiska. W razie wystąpienia szkody spowodowanej wprowadzaniem ścieków w ramach działalności wymagającej pozwolenia wodnoprawnego, stosuje się przepisy ustawy z dnia 13 kwietnia 2007 r. o zapobieganiu szkodom w środowisku i ich napra$w^{1} \mathrm{e}^{100}$. Tym niemniej dla wód opadowych przytoczone przepisy wydają się raczej posiadać charakter uzupełniający w stosunku do art. 29 Prawa wodnego. Nie wykluczają także niezależnego poniesienia przez korzystającego z wód zarówno odpowiedzialności karnej ${ }^{101}$, jak i cywilnej ${ }^{102}$.

Wprowadzający ścieki do wód lub do ziemi obowiązani są zapewnić ochronę wód przed zanieczyszczeniem, głównie przez budowę i eksploatację urządzeń służących tej ochronie, a tam gdzie jest to celowe, powtórne wykorzystanie oczyszczonych ścieków. Budowę urządzeń służących do zaopatrzenia w wodę realizuje się jednocześnie z rozwiązaniem spraw gospodarki ściekowej, w szczególności przez budowę systemów kanalizacji zbiorczej i oczyszczalni ścieków, spełniających wymagania ochrony środowiska ${ }^{103}$. Wyłącznie w miejscach, gdzie budowa systemów kanalizacji zbiorczej nie przyniosłaby korzyści dla środowiska lub powodowałaby nadmierne koszty, należy stosować systemy indywidualne lub inne rozwiązania zapewniające

99 Zob. K. Gruszecki, Prawo ochrony środowiska. Komentarz, Warszawa 2011, s. 683.

100 Dz.U. Nr 75, poz. 493 ze zm.

101 Zob. art. 351 ust. 1 Prawa ochrony środowiska oraz art. 192 ust. 3 Prawa wodnego i art. 28 ust. 1 ustawy o zapobieganiu szkodom w środowisku i ich naprawie.

102 Zob. art. 323 Prawa ochrony środowiska.

103 Zob. art. 76 ust. 1-4 Prawa ochrony środowiska. 
ochronę środowiska (art. 42 Prawa wodnego z 2001 r.). Trzeba jednak wspomnieć, że w myśl art. 43 ust. 1 Prawa wodnego z 2001 r., aglomeracje o równoważnej liczbie mieszkańców powyżej 2000 powinny być wyposażone w systemy kanalizacji zbiorczej dla ścieków komunalnych, zakończone oczyszczalniami ścieków, zgodnie z ustaleniami krajowego programu oczyszczania ścieków komunalnych ${ }^{104}$. W rezultacie zwłaszcza na obszarach silniej zurbanizowanych regułą stało się wprowadzanie wód opadowych do funkcjonujących urządzeń kanalizacyjnych, a odprowadzanie wód opadowych do wód płynących, stojących lub ewentualnie do wód podziemnych ma miejsce najczęściej na pozostałych terenach.

Odnosząc się do wprowadzania wód opadowych do urządzeń kanalizacyjnych ${ }^{105}$ nie sposób nie dostrzec, iż Prawo wodne z 2001 r. poza wspomnianymi wymogami w zakresie budowy oczyszczalni ścieków ${ }^{106}$, a także nałożeniem w art. 122 ust. 1 pkt 10 nieznanego dotychczas obowiązku posiadania pozwolenia wodnoprawnego na wprowadzanie do urządzeń kanalizacyjnych (będących własnością innych podmiotów) ścieków przemysłowych, zawierających substancje szczególnie szkodliwe dla środowiska wodnego, określone w przepisach wydanych na podstawie art. 45 a ust. $1^{107}$, pomija owe zagadnienia. Pozo-

104 Zob. obwieszczenie Ministra Środowiska z dnia 2 lipca 2010 r. w sprawie ogłoszenia krajowego programu oczyszczania ścieków komunalnych oraz jego dwóch aktualizacji, M.P. Nr 58, poz. 775, a także obwieszczenie Ministra Środowiska z dnia 5 kwietnia 2011 r. w sprawie ogłoszenia aktualizacji krajowego programu oczyszczania ścieków komunalnych, M.P. Nr 62, poz. 589.

105 Przez urządzenia kanalizacyjne należy rozumieć sieci kanalizacyjne, wyloty urządzeń kanalizacyjnych służących do wprowadzania ścieków do wód lub do ziemi oraz urządzenia podczyszczające i oczyszczające ścieki oraz przepompownie ścieków (art. 2 pkt 14 ustawy o zbiorowym zaopatrzeniu w wodę i zbiorowym odprowadzaniu ścieków).

106 Mającymi na celu realizację dyrektywy Rady 91/271/EWG z dnia 21 maja 1991 r. dotyczącej oczyszczania ścieków komunalnych, Dz.Urz. WE L 135/40 z 30.5. 1991.

107 Zob. rozporządzenie Ministra Środowiska z dnia 10 listopada 2005 r. w sprawie substancji szczególnie szkodliwych dla środowiska wodnego, których wprowadzanie w ściekach przemysłowych do urządzeń kanalizacyjnych wymaga uzyskania pozwolenia wodnoprawnego, Dz.U. Nr 233, poz. 1988 ze $\mathrm{zm}$. 
stawiono wszakże ich uregulowanie ustawie z dnia 7 czerwca 2001 r. o zbiorowym zaopatrzeniu w wodę i zbiorowym odprowadzaniu ścieków ${ }^{108}$, która co prawda miała w zamyśle ustawodawcy uchylić omówione już przepisy art. 98-107 Prawa wodnego z 1974 r., ale weszła w życie później niż Prawo wodne z 2001 r.

Zbiorowe zaopatrzenie w wodę i zbiorowe odprowadzanie ścieków jest zadaniem własnym gminy, realizowanym niekiedy wspólnie z innymi gminami. Dlatego też to gmina ustala kierunki rozwoju sieci w studium uwarunkowań i kierunków zagospodarowania przestrzennego gminy w miejscowym planie zagospodarowania przestrzennego ${ }^{109}$ (art. 3 ust. 1-3 ustawy o zbiorowym zaopatrzeniu w wodę i zbiorowym odprowadzaniu ścieków). Zadania w zakresie zbiorowego zaopatrzenia w wodę lub zbiorowego odprowadzania ścieków są natomiast wykonywane bezpośrednio przez przedsiębiorstwo kanalizacyjne w rozumieniu art. 2 pkt 4 tej ustawy, przez które należy rozumieć przedsiębiorcę $\mathrm{w}$ rozumieniu przepisów o swobodzie działalności gospodarczej ${ }^{110}$ prowadzącego działalność $\mathrm{w}$ zakresie zbiorowego zaopatrzenia $\mathrm{w}$ wodę lub zbiorowego odprowadzania ścieków oraz gminne jednostki organizacyjne nieposiadające osobowości prawnej, prowadzące tego rodzaju działalność. Na prowadzenie zbiorowego zaopatrzenia w wodę i zbiorowego odprowadzania ścieków jest wymagane uzyskanie zezwolenia wydawanego przez wójta (burmistrza, prezydenta miasta) w drodze decyzji, jakkolwiek nie mają obowiązku uzyskania zezwolenia gminne jednostki organizacyjne (art. 16 ust. 1 i 3 ustawy o zbiorowym zaopatrzeniu w wodę i zbiorowym odprowadzaniu ścieków).

108 Tj. Dz.U. z 2006 r. Nr 123, poz. 858 ze zm.

109 Zob. art. 10 ust. 1 oraz art. 15 ust. 2 ustawy z dnia 27 marca 2003 r. o planowaniu i zagospodarowaniu przestrzennym, Tj. Dz.U. z 2012 r., poz. 647 ze zm.

110 Zob. art. 4 ust. 1 i 2 ustawy z dnia 2 lipca 2004 r. o swobodzie działalności gospodarczej, Tj. Dz.U. z 2013 r., poz. 672 ze zm. 
Przedsiębiorstwo wodociągowo-kanalizacyjne powinno zapewnić budowę m.in. urządzeń kanalizacyjnych ${ }^{111}$, ustalonych przez gminę w studium uwarunkowań i kierunków zagospodarowania przestrzennego gminy oraz miejscowych planach zagospodarowania przestrzennego, w zakresie uzgodnionym $\mathrm{w}$ wieloletnim planie rozwoju i modernizacji, opracowanym przez to przedsiębiorstwo i uchwalonym przez radę gminy (art. 15 ust. 1 ustawy o zbiorowym zaopatrzeniu w wodę i zbiorowym odprowadzaniu ścieków). Realizację budowy przyłączy do sieci wraz z pomieszczeniem do lokalizacji urządzenia pomiarowego zapewnia na własny koszt osoba ubiegająca się o przyłączenie oraz ponosi koszt nabycia tego urządzenia, a przedsiębiorstwo wodociągowo-kanalizacyjne jest obowiązane przyłączyć do sieci nieruchomości osoby ubiegającej się o ich przyłączenie do sieci, jeżeli są spełnione warunki przyłączenia określone w regulaminie, a także istnieją techniczne możliwości świadczenia usług (art. 15 ust. 2-4 cytowanej ustawy). Odprowadzanie ścieków odbywa się na podstawie pisemnej umowy zawartej między przedsiębiorstwem wodociągowo-kanalizacyjnym a odbiorcą usług (art. 6 ust. 1 ustawy o zbiorowym zaopatrzeniu w wodę i zbiorowym odprowadzaniu ścieków) ${ }^{112}$. Zabronione jest m.in. wprowadzanie ścieków bytowych ${ }^{113}$ i ścieków przemysło-

111 Odnośnie aktualnych metod projektowania kanalizacji deszczowej zob. B. Kaźmierczak, A. Kotowski: O modelowaniu działania kanalizacji deszczowej w terenie płaskim, „Gospodarka Wodna” 2012, nr 7, s. 292-300; B. Kaźmierczak, A. Kotowski, Ocena przydatności dotychczasowych wzorów na natężenie opadów deszczowych do projektowania odwodnień terenów w Polsce, „Gaz, Woda i Technika Sanitarna" 2009, nr 11, s. 11-16; P. Licznar, Potrzeba wykorzystania syntetycznych danych opadowych dla modelowania sieci kanalizacji deszczowej i ogólnospławnej, „Gaz, Woda i Technika Sanitarna” 2009, nr 6, s. 19-23; A. Kotowski, Modele opadów do bezpiecznego projektowania kanalizacji, „Rynek Instalacyjny" 2011, nr 9, s. 46-50.

112 Jednocześnie, zgodnie z art. 28 ust. 4 ustawy o zbiorowym zaopatrzeniu $\mathrm{w}$ wodę i zbiorowym odprowadzaniu ścieków, odprowadzanie ścieków bez zawarcia odpowiedniej umowy podlega karze ograniczenia wolności albo grzywny do 10 tys. zł.

113 Ścieki bytowe to ścieki z budynków mieszkalnych, zamieszkania zbiorowego oraz użyteczności publicznej, powstające w wyniku ludzkiego meta- 
wych ${ }^{114}$ do urządzeń kanalizacyjnych przeznaczonych do odprowadzania wód opadowych, a także ścieków opadowych i wód drenażowych do kanalizacji sanitarnej (art. 9 ust. 1 ustawy o zbiorowym zaopatrzeniu w wodę i zbiorowym odprowadzaniu ścieków). Pierwszy z zakazów ma na celu ochronę kanalizacji deszczowej przed skutkami technologicznymi i technicznymi zanieczyszczenia innymi ściekami, drugi zaś zapobieganie przeciążeniom i zakłóceniu w pracy oczyszczalni ścieków, spowodowanej wprowadzeniem wód opadowych i drenażowych do kanalizacji sanitarnej ${ }^{115}$.

Sposób realizacji obowiązków dostawców ścieków przemysłowych oraz warunki wprowadzania ścieków przemysłowych do urządzeń kanalizacyjnych oraz sposób sprawowania kontroli ilości i jakości ścieków zostały dookreślone w rozporządzeniu Ministra Budownictwa z dnia 14 lipca 2006 r. w sprawie sposobu realizacji obowiązków dostawców ścieków przemysłowych oraz warunków wprowadzania ścieków do urządzeń kanalizacyjnych $^{116}$, wydanym na podstawie art. 11 ustawy o zbiorowym zaopatrzeniu $\mathrm{w}$ wodę i zbiorowym odprowadzaniu ścieków. Podobnie, na podstawie przewidzianej $\mathrm{w}$ tej ustawie delegacji (art. 23 ust. 1), wydano przepisy wykonawcze odnośnie szczegółowego określenia taryf zatwierdzanych w drodze uchwały rady gminy i zawierających ceny oraz stawki opłat, tj. rozporządzenie Ministra Budownictwa z dnia 28 czerwca 2006 r. w sprawie określenia taryf, wzoru wniosku o zatwierdzenie taryf oraz warunków rozliczeń za zbiorowe zaopatrzenie w wodę i zbio-

bolizmu lub funkcjonowania gospodarstw domowych oraz ścieki o zbliżonym składzie pochodzące z tych budynków (art. 2 pkt 9 ustawy o zbiorowym zaopatrzeniu w wodę i zbiorowym odprowadzaniu ścieków).

114 Ścieki przemysłowe to ścieki, niebędące ściekami bytowymi albo wodami opadowymi lub roztopowymi, powstałe $\mathrm{w}$ związku z prowadzoną przez zakład działalnością handlową, przemysłową, składową, transportową lub usługową, a także będące ich mieszaniną ze ściekami innego podmiotu, odprowadzane urządzeniami kanalizacyjnymi tego zakładu (art. 2 pkt 11 ustawy o zbiorowym zaopatrzeniu w wodę i zbiorowym odprowadzaniu ścieków).

115 J. Wiśniewski, Ustawa o zbiorowym zaopatrzeniu $w$ wodę i zbiorowym odprowadzaniu ścieków z komentarzem, Bydgoszcz 2001, s. 22.

116 Dz.U. Nr 136, poz. 964. 
rowe zaopatrzenie ścieków ${ }^{117}$. Zgodnie z § 5 pkt 4 i 5 lit. a tego rozporządzenia, taryfy zawierają ${ }^{118}$ cenę za jednostkę miary powierzchni zanieczyszczonej o trwałej nawierzchni, z której odprowadzane są ścieki opadowe lub roztopowe kanalizacją deszczową, uwzględniającą rodzaj i sposób zagospodarowania powierzchni, a także stawkę opłaty abonamentowej w rozliczeniach za ścieki opadowe i roztopowe odprowadzane kanalizacją deszczową ${ }^{119}$. Problematyczne jest jednak stosowanie tych przepisów do wód opadowych i roztopowych spływających z połaci dachowych, skoro ustawodawca wiąże powierzchnie zanieczyszczone z terenami, czyli powierzchnią ziemi ${ }^{120}$. Nie są one więc ściekami, nawet jeśli obiekty budowlane znajdują się na terenie miast ${ }^{121}$.

117 Dz.U. Nr 127, poz. 886.

118 Zawyżenie taryfy oraz nie przedstawienie przez przedsiębiorstwo wodociągowo-kanalizacyjne taryfy do zatwierdzenia może skutkować nałożeniem na nie kary pieniężnej przez wójta (burmistrza, prezydenta miasta) w oparciu o przepisy art. 29 ustawy o zbiorowym zaopatrzeniu w wodę i zbiorowym odprowadzaniu ścieków.

119 W przypadku odprowadzania ścieków opadowych i roztopowych kanalizacją ogólnospławną nie ustala się ceny za usługę, lecz uznaje koszty ich odprowadzania za koszty wspólne dla wszystkich taryfowych grup odbiorców usług kanalizacyjnych ( $\S 11$ ust. 2 rozporządzenia Ministra Budownictwa z dnia 28 czerwca 2006 r.), co w konsekwencji oznacza, że ponoszą je także ci, którzy ich w ogóle nie odprowadzają. Zob. P. Bojarski, W. Radecki, J. Rotko, Ustawa o zbiorowym zaopatrzeniu $w$ wodę i zbiorowym odprowadzaniu ścieków. Komentarz, Warszawa 2011, s. 196. Na problemy dotyczące opłat za wody opadowe i roztopowe zwracają uwagę H. Kłoss-Trębaczkiewicz, E. Osuch-Pajdzińska, Zasady ustalania taryf za odprowadzanie wód opadowych i roztopowych do kanalizacji deszczowej, „Gaz, Woda i Technika Sanitarna” 2007, nr 7-8, s. 19-22, a także B. Rakoczy, Zbiorowe zaopatrzenie $w$ wode $i$ zbiorowe odprowadzanie ścieków $w$ praktyce przedsiębiorstw wodociąowo-kanalizacyjnych, Bydgoszcz 2012, s. 123-124.

120 Zob. M. Krzyszczak, Prawo a odprowadzanie ścieków opadowych, „Wodociągi - Kanalizacja" 2008, nr 4, s. 38; B. Dziadkiewicz, Zbiorowe zaopatrzenie $w$ wodę i odprowadzanie ścieków. Komentarz do przepisów, umowy, taryfy, regulaminy, orzecznictwo, Warszawa 2011, s. 35-36.

121 Zob. wyrok Naczelnego Sądu Administracyjnego z dnia 24 maja 2007 r. - II OSK 256/07, publ. http://orzeczenia.nsa.gov.pl/doc/6CDD28E0C7. 
Omówienie całości zagadnienia byłoby niepełne bez sięgnięcia do ustawy o utrzymaniu porządku i czystości w gminach, która wciąż obowiązuje, choć jej znaczenie dla odprowadzania wód opadowych jest mniejsze niż poprzedzających ją aktów normatywnych. Określa ona zasady postępowania z nieczystościami ciekłymi wyłącznie w rozumieniu art. 2 ust. 1 pkt 1, czyli ściekami gromadzonymi przejściowo w zbiornikach bezodpływowych, do których z zasady nie wprowadza się wód opadowych. Nakłada także na właścicieli nieruchomości wskazany wcześniej obowiązek przyłączenia nieruchomości do istniejącej sieci kanalizacyjnej (art. 5 ust. 1 pkt 2), chyba że budowa sieci kanalizacyjnej jest technicznie lub ekonomicznie nieuzasadniona. W takich okolicznościach niezbędne jest wyposażenie nieruchomości we wspomniany zbiornik bezodpływowy lub w przydomową oczyszczalnię ścieków bytowych ${ }^{122}$. Posiadanie oczyszczalni zwalnia jednocześnie z obowiązku przyłączenia nieruchomości do wykonywanej sieci kanalizacyjnej.

Przytoczone obowiązki korelują z wprowadzonymi na mocy Prawa budowlanego z 1994 r. warunkami w zakresie projektowania ${ }^{123}$ i budowy ${ }^{124}$ oraz utrzymania obiektów budowlanych ${ }^{125} \mathrm{~W}$ sposób zgodny z obowiązującymi przepisami, zakładającymi konieczność spełnienia przez inwestora oraz innych

122 Brak wyposażenia i przyłączenia nieruchomości do istniejącej sieci kanalizacyjnej jest wykroczeniem z art. 10 ust. 2 ustawy o utrzymaniu porządku i czystości w gminach.

123 Decydujące znaczenie dla określenia zawartości projektu budowlanego posiadało dotychczas rozporządzenie Ministra Infrastruktury z dnia 3 lipca 2003 r. w sprawie szczegółowego zakresu i formy projektu budowlanego, Dz.U. Nr 120, poz. 1133 ze zm. Zostało ono pośrednio uchylone na mocy art. 35 pkt 1 ustawy z dnia 16 września 2011 r. o ochronie praw nabywcy lokalu mieszkalnego lub domu jednorodzinnego, Dz.U. Nr 232, poz. 1377. Obecnie obowiązuje nowe rozporządzenie Ministra Transportu, Budownictwa i Gospodarki Morskiej z dnia 25 kwietnia 2012 r. w sprawie szczegółowego zakresu i formy projektu budowlanego, Dz.U. z 2012 r., poz. 462 ze zm.

124 Odnośnie uczestników procesu budowlanego i ich obowiązków zob. art. 17-27 Prawa budowlanego.

125 W kwestii użytkowania budynków mieszkalnych zob. rozporządzenie Ministra Spraw Wewnętrznych i Administracji z dnia 16 sierpnia 1999 r. w sprawie warunków technicznych użytkowania budynków mieszkalnych, Dz.U. Nr 74, poz. 836 ze zm. 
uczestników procesu budowlanego wymagań związanych m.in. z ochroną środowiska oraz usuwaniem ścieków i wody opadowej ${ }^{126}$. Zasadniczą rolę odgrywają zaś w tej materii wydane akty wykonawcze do rzeczonej ustawy. Zwłaszcza chodzi o rozporządzenie Ministra Infrastruktury z dnia 12 kwietnia 2002 r. w sprawie warunków technicznych, jakim powinny odpowiadać budynki i ich usytuowanie ${ }^{127}$, a także w mniejszym stopniu o inne przepisy kształtujące pewne specyficzne rozwiązania, w zależności od konkretnych rodzajów wznoszonych obiektów budowlanych $^{128}$.

126 Naruszenie wymienionych warunków stanowi wykroczenie z art. 93 pkt 6 Prawa budowlanego i może skutkować nałożeniem kary grzywny. Do tego warto dodać, że wspomniana ustawa w art. 95 pkt 3 wprowadza również odpowiedzialność zawodową w budownictwie. Podlegają jej osoby wykonujące samodzielne funkcje techniczne w budownictwie, które m.in. spowodowały zagrożenie dla środowiska. Po zakończeniu budowy kluczową rolę dyscyplinującą odgrywają natomiast przepisy art. 91a Prawa budowlanego, które penalizują uchybienie obowiązkowi utrzymania obiektu budowlanego w należytym stanie technicznym i jego użytkowania w sposób zgodny z obowiązującymi przepisami.

127 Dz.U. Nr 75, poz. 690 ze zm.

128 Zob. rozporządzenie Ministra Gospodarki z dnia 26 kwietnia 2013 r. w sprawie warunków technicznych, jakim powinny odpowiadać sieci gazowe i ich usytuowanie, Dz.U. z 2013 r. poz. 640; rozporządzenie Ministra Transportu i Gospodarki Morskiej z dnia 26 lutego 1996 r. w sprawie warunków technicznych, jakim powinny odpowiadać skrzyżowania linii kolejowych z drogami publicznymi i ich usytuowanie, Dz.U. Nr 33, poz. 144 ze zm.; rozporządzenie Ministra Gospodarki z dnia 21 listopada 2005 r. w sprawie warunków technicznych, jakim powinny odpowiadać bazy i stacje paliw płynnych, rurociągi przesyłowe dalekosiężne służące do transportu ropy naftowej i produktów naftowych i ich usytuowanie, Dz.U. Nr 243, poz. 2063 ze zm.; rozporządzenie Ministra Rolnictwa i Gospodarki Żywnościowej z dnia 7 października 1997 r. w sprawie warunków technicznych, jakim powinny odpowiadać budowle rolnicze i ich usytuowanie, Tj. Dz.U. z 2014 r., poz. 81; rozporządzenie Ministra Transportu i Gospodarki Morskiej z dnia 1 czerwca 1998 r. w sprawie warunków technicznych, jakim powinny odpowiadać morskie budowle hydrotechniczne i ich usytuowanie, Dz.U. Nr 101, poz. 645; rozporządzenie Ministra Transportu i Gospodarki Morskiej z dnia 10 września 1998 r. w sprawie warunków technicznych, jakim powinny odpowiadać budowle kolejowe i ich usytuowanie, Dz.U. Nr 151, poz. 987; rozporządzenie Ministra Transportu i Gospodarki Morskiej z dnia 2 marca 1999 r. w sprawie warunków technicznych, jakim powinny odpowiadać drogi publiczne i ich usytuowanie, 
Cytowane rozporządzenie ustala warunki dla budynków i związanych z nimi urządzeń, wraz z ich usytuowaniem na działce budowlanej oraz zagospodarowaniem działek przeznaczonych pod zabudowę, utrzymując w zasadzie wcześniejsze rozwiązania dotyczące odprowadzania wód opadowych z projektowanych obiektów budowlanych ${ }^{129}$. Stanowi, że działka budowlana pod zabudowę budynkami przeznaczonymi na pobyt ludzi powinna mieć zapewnioną możliwość przyłączenia uzbrojenia działki lub bezpośrednio budynku m.in. do sieci kanalizacyjnej, a tylko w razie braku warunków przyłączenia dopuszcza się zastosowanie zbiornika bezodpływowego lub przydomowej oczyszczalni ścieków (§ 26 ust. 1 i 3). Stąd działka, na której są sytuowane budynki, powinna być wyposażona w kanalizację umożliwiającą odprowadzenie wód opadowych do sieci kanalizacji deszczowej lub ogólnospławnej. Jedynie przy braku możliwości przyłączenia do sieci takowej kanalizacji dopuszcza się wprowadzanie wód opadowych na własny teren nieutwardzony lub do dołów chłonnych, a także do zbiorników retencyjnych (§ 28 ust. 2), co akurat okazuje się pewnym novum w stosunku do stanu wcześniejszego ${ }^{130}$. W przypadku późniejszego wykorzystania wód opadowych ${ }^{131}$ zgromadzonych w takich zbiorni-

Dz.U. Nr 43, poz. 430 ze zm.; rozporządzenie Ministra Transportu i Gospodarki Morskiej z dnia 30 maja 2000 r. w sprawie warunków technicznych, jakim powinny odpowiadać drogowe obiekty inżynierskie i ich usytuowanie, Dz.U. Nr 63, poz. 735 ze zm.; rozporządzenie Ministra Infrastruktury z dnia 16 stycznia 2002 r. w sprawie przepisów techniczno-budowlanych dotyczących autostrad płatnych, Dz.U. Nr 12, poz. 116 ze zm.; rozporządzenie Ministra Środowiska z dnia 30 kwietnia 2013 r. w sprawie składowisk odpadów, Dz.U. z 2013 r., poz. 523.

129 Odprowadzanie wód opadowych pod kątem poprawnego zwymiarowania odwodnień omawia A. Ujma, Analiza wytycznych wymiarowania odwodnień dachowych, „Rynek Instalacyjny” 2009, nr 10, s. 88-92.

130 Odnośnie różnych rozwiązań w zakresie wykorzystania wód opadowych zob. http://muratordom.pl/instalacje-kanalizacyjne/co-zrobic-zdeszczowka,38_..., http://muratordom.pl/instalacje-kanalizacyjne/jak-zagospodarowac-wode-d..., http://muratordom.pl/instalacje-kanalizacyjne/ odwodnienie,38_2099.html?..., http://muratordom.pl/instalacje-kanalizacyjne/co-zrobic-z-deszczowka,38_.

131 Zob. M. Zawilski, G. Sakson, Systemy wykorzystywania wody deszczowej i ich wptyw na funkcjonowanie kanalizacji miejskiej, „Gaz, Woda i Technika Sanitarna" 2004, nr 9, s. 298-302. 
kach (do spłukiwania toalet, podlewania zieleni, mycia dróg i chodników oraz potrzeb gospodarczych ${ }^{132}$ ) niezbędne jest wykonanie odrębnej instalacji, niepołączonej z instalacją wodociągową (§ 126 ust. 3). Należy jednak mieć świadomość, że zgodnie z § 29 rozporządzenia Ministra Infrastruktury z 2002 r. dokonywanie zmiany naturalnego spływu wód opadowych w celu kierowania ich na teren sąsiedniej nieruchomości jest zabronione, zarówno podczas realizacji inwestycji budowlanej, jak i po jej zakończeniu ${ }^{133}$, i to nawet za zgodą jej właściciela ${ }^{134}$.

\section{USTALENIA I WNIOSKI}

W rezultacie niniejszych wywodów jawi się dość jednoznaczna konkluzja, co do zasadniczego pytania w sprawie statusu wód opadowych. Bez wątpienia wody opadowe znajdujące się na powierzchni ziemi przynależą do śródlądowych wód powierzchniowych, ze wszystkimi skutkami z tego faktu wynikającymi. Występują aliści dość istotne różnice między nimi. Takie same chemicznie wody opadowe mogą wszak zostać jednocześnie zakwalifikowane na gruncie obowiązujących przepisów jako ścieki, w zależności od przyjętej klasyfikacji terenu i rodzaju powierzchni, na której znalazł się opad oraz wykonanych urządzeń służących ich ujmowaniu, co w zasadniczym stopniu rzutuje na dopuszczalny sposób zagospodarowania deszczówki. Niebagatelne znaczenie ma w tym względzie także kwestia charakteru odbiornika wód opadowych i ilości wód do niego kierowanych. W konsekwencji odprowadzenie wód opadowych

132 Oprócz wód opadowych do takich celów wykorzystywane są tzw. szare wody. Zob. A. Jodłowski, J. Mucha, Ocena możliwości wykorzystania wody szarej, „Gaz, Woda i Technika Sanitarna” 2010, nr 7-8, s. 24-27. Odnośnie do definicji szarej wody zob. http://pl.wikipedia.org/wiki/Szara_woda

133 Zob. uzasadnienie do wyroku Wojewódzkiego Sądu Administracyjnego w Lublinie z dnia 18 lutego 2009 r. - II SA/Lu 786/08, publ. System Informacji prawnej LEX nr 533180.

134 Zob. M. Kosiarski, Czy wolno odprowadzać wodę z dachu na dziatkę sąsiada, „Gazeta Prawna” 2012, nr 11 (3149). 
do śródlądowych wód płynących odbywa się zawsze za pozwoleniem wodnoprawnym, niezależnie od tego, czy mamy do czynienia z wodami o cechach ścieków opadowych, ale już same warunki uprawnienia są zgoła odmienne.

Odprowadzanie wód opadowych do wód stojących może funkcjonować albo w ramach szczególnego korzystania z wód (za pozwoleniem wodnoprawnym), albo zwykłego korzystania z wód (bez pozwolenia wodnoprawnego) - kiedy właścicielem wód stojących oraz wód opadowych jest ten sam podmiot, a ilość odprowadzanej wody nie przekracza $5 \mathrm{~m}^{3}$ na dobę. Wprowadzanie wód opadowych do ziemi jest z kolei korzystaniem z wód wyłącznie wówczas, jeśli są one jednocześnie ściekami. Choć gdy nie mamy wcale do czynienia z korzystaniem z wód, to i tak zabronione są wszelkie działania powodujące szkodliwą dla gruntów sąsiednich zmianę stanu wody na gruncie oraz sztuczne odprowadzanie wody na grunty sąsiednie.

Dozwolone jest wprawdzie swobodne pozyskiwanie i zużywanie deszczówki przez właścicieli gruntów, zwłaszcza że wyłapujące wody opadowe urządzenia techniczne nie są z reguły urządzeniami wodnymi (np. rynny ze spustami), aczkolwiek wody opadowe $\mathrm{z}$ działek zabudowanych zasadniczo powinny zostać wprowadzone do urządzeń kanalizacyjnych. Dopiero brak ku temu odpowiednich warunków dopuszcza ich odmienne zagospodarowanie. Pomimo więc licznych zmian przepisów na przestrzeni kilkudziesięciu lat, wprowadzanie wód opadowych do urządzeń kanalizacyjnych stanowiło i nadal stanowi regułę na terenach zurbanizowanych, skoro wszelkie inne rozwiązania alternatywne ${ }^{135}$ znajdują zastosowanie tylko $\mathrm{w}$ razie

135 Co do rozwiązań alternatywnych zob. M. Bogacz-Rygas, Aspekty ekologiczne stosowania nowych rozwiąań odprowadzania wód opadowych i ich zagospodarowanie. Nowe urzadzenia, materiały i technologie $w$ wodociagach i kanalizacji, Kielce 2007, s. 1-5; K. Gudelis-Matys, Zagospodarowanie ścieków deszczowych $w$ zakładach przemysłowych, „Magazyn Przemysłu Rybnego” 2004, nr 3(39), s. 7; K. Gudelis-Taraszkiewicz, Zagospodarowanie wód opadowych - polskie doświadczenia w eksploatacji komór drenażowych, [w:] Materiaty z seminarium pt. Wody opadowe. Status prawny, opłaty, technologie, Gdańsk-Sobieszewo 2006, s. 2-13; Z. Małecki, Ochrona wód. Część VII, „Ekotechnika” 2006, nr 2(38), s. 17-18; Z. Suligowski, K. Gudelis-Taraszkiewicz, Alternatyw- 
braku istniejącej sieci. O ile trudno kwestionować zasadność owej reguły w minionym okresie, o tyle obecnie wydaje się ona nie tylko niewłaściwą, ale i sprzeczną z dyrektywą 2000/60/WE z dnia 23 października 2000 r. ustanawiającą ramy wspólnotowego działania w dziedzinie polityki wodnej ${ }^{136}$. Zgodnie ze wspomnianą dyrektywą woda nie jest produktem handlowym, takim jak każdy inny, wobec czego należy ją chronić, co między innymi odbywa się poprzez eliminowanie jej zanieczyszczania oraz zwiększenie integracji aspektów ilościowych i jakościowych zarówno wód powierzchniowych, jak i podziemnych, uwzględniając naturalne warunki przepływu wody w cyklu hydrologicznym.

Tymczasem odprowadzanie wód deszczowych bezpośrednio do wód powierzchniowych ${ }^{137}$, albo zbieranie i wprowadzanie ich do urządzeń kanalizacyjnych, gdzie dochodzi najczęściej do ich zmieszania ze ściekami bytowymi lub przemysłowymi i pierwotnego lub wtórnego zanieczyszczenia, skutkuje marnotrawieniem wody i wzrostem wydatków na oczyszczanie ścieków. W efekcie bowiem wody opadowe rychło trafiają do wód płynących, co powoduje stepowienie terenów (z racji coraz większej powierzchni szczelnej zabudowy), przy jednoczesnym dochodzeniu do gwałtownych wezbrań cieków i podtopień poniżej wylotu. Ponadto wody opadowe docierające do oczyszczalni siecią kanalizacji ogólnospławnej mogą doprowadzić przy znacznych wahaniach $\mathrm{w}$ ich ilości do utrudnień w pracy oczyszczalni oraz częstych zrzutów awaryjnych ścieków nie-

ne rozwiązania kanalizacji wód opadowych, „Gaz, Woda i Technika Sanitarna” 2003, nr 12, s. 423-426; E. Burszta-Adamiak, Zrównoważone gospodarowanie wodami opadowymi, „Rynek Instalacyjny” 2010, nr 9, s. 56-58; A. Januchta-Szostak, Alternatywa dla tradycyjnej kanalizacji?, „Przegląd Komunalny” 2011, nr 11, s. 92/97.

136 Dz.Urz. WE L 327 z 22. 12. 2000.

137 W niektórych przypadkach dozwolone jest wprowadzanie wód zużytych do wód podziemnych, stosownie do art. 11 ust. 3 lit. j cytowanej dyrektywy. Zob. K. Szuma, J. Szuma, Wdrażanie ramowej dyrektywy wodnej w Polsce. Zagadnienia wybrane, [w:] B. Rakoczy (red.), Wybrane problemy prawa wodnego, Warszawa 2013, s. 69. Nie obejmują one jednak przypadku odprowadzania do nich wód opadowych. 
czyszczonych wprost do odbiorników ${ }^{138}$. Dlatego konieczne jest odwrócenie tego niekorzystnego zjawiska, poprzez ukierunkowanie na rozwiązania nieingerujące $\mathrm{w}$ naturalny obieg wód w przyrodzie ${ }^{139}$. Woda deszczowa powinna w większym stopniu pozostać w miejscu wystąpienia opadu, infiltrując stopniowo do wód podziemnych ${ }^{140}$. Niemniej brak jeszcze rozwiązań prawnych oraz instrumentów ekonomicznych podążających $\mathrm{w}$ tym kierunku ${ }^{141}$. Pojawia się zresztą następny problem, dotyczący wprowadzania wód opadowych do urządzeń kanalizacyjnych, odbywający się na podstawie pisemnej umowy zawartej między przedsiębiorstwem wodociągowo-kanalizacyjnym a odbiorcą usług. Wydane na podstawie ustawy o zbiorowym zaopatrzeniu w wodę i zbiorowym odprowadzaniu ścieków przepisy wykonawcze $\mathrm{w}$ sprawie szczegółowego określenia taryf oraz warunków rozliczeń za zbiorowe zaopatrzenie w wodę i zbiorowe odprowadzanie ścieków pozwalają na ustalenie stawki opłaty abonamentowej wyłącznie za ścieki, czyli m.in. zanieczyszczone wody opadowe ${ }^{142}$. Zasadne są zatem sygnalizowane wcześniej wątpliwości odnośnie do możliwości ich stosowania do wprowadzania do urządzeń kanalizacyjnych znacznej części wód opadowych, które nie są jednocześnie ściekami ${ }^{143}$.

138 http://www.swiatowydzienwody.pl/pic/wody\%20opadowe\%20w\%20 przepisach.pdf.

139 Zob. Zagospodarowanie wód deszczowych w sposób zbliżony do naturalnego, „Gaz, Woda i Technika Sanitarna” 2001, nr 8, s. 296.

140 Zob. K. Gudelis-Taraszkiewicz, Jak walczyć z powodzią? (1). Retencja wskazana, „Magazyn Instalatora 2010, nr 7-8 (143-144), s. 61.

141 Zob. J. Królikowska, A. Królikowski, Wody opadowe. Odprowadzanie, zagospodarowanie, podczyszczanie i wykorzystanie, Warszawa 2012, s. 64.

142 Problematykę opłat za wody opadowe rozwijają H. Bylka, J. Skiba, Uwarunkowania prawne, ekonomiczne $i$ administracyjne zwiazane z pobieraniem opłat za wody opadowe, „Gaz, Woda i Technika Sanitarna” 2012, nr 1, s. 34-40.

143 Odnośnie propozycji zaradczej, idącej w kierunku ustalenia opłaty lokalnej za wprowadzanie czystych wód opadowych do kanalizacji deszczowej zob. D. Gusta, T. Płonka, Do utrzymania kanalizacji deszczowej nie trzeba dopłacać, „Gazeta Samorządu i Administracji” 2007, nr 9 (235), s. 18; M. Marczuk, Koszty wody z nieba, „Gazeta Prawna” 2004, nr 114 (1223); M. Kryszkiewicz, Rady gmin wprowadzaja podatek od deszczu, „Gazeta Prawna” 2009, 
Pozytywnie należy ocenić konieczność posiadania, co do zasady, pozwolenia wodnoprawnego nie tylko na wprowadzanie zanieczyszczonych wód opadowych do wód śródlądowych lub do ziemi, ale także na wprowadzanie wód do wód. Odprowadzana deszczówka nierzadko przecież stanowi znaczący składnik wód płynących, a czasami nawet zasadniczą część wód prowadzonych przez niektóre cieki wodne ${ }^{144}$. Podobne racje wskazują na celowość stosowania przepisów o korzystaniu z wód do wód znajdujących się w rowach. W przedmiocie zmiany stanu wodny na gruncie oraz odprowadzania wód i ścieków na grunty sąsiednie w dalszym ciągu pozostaje natomiast otwarta kwestia wzajemnych powiązań na styku Prawa wodnego i Prawa budowlanego ${ }^{145}$, wymagająca dodatkowego uwzględnienia przepisów dotyczących zmiany zagospodarowania terenu ${ }^{146}$, co jest niezmiernie istotne, bo w większości przypadków do zakłócenia stosunków wodnych dochodzi wskutek różnorakich inwestycji, dopuszczonych do realizacji po wcześniejszym przeznaczeniu dotychczasowych gruntów rolnych na cele budowlane.

Podsumowując, nasuwają się trzy kluczowe postulaty de lege ferenda. Przede wszystkim widoczna jest potrzeba odpowiedniej nowelizacji Prawa wodnego z 2001 r., która spowoduje umiejscowienie wód opadowych pośród śródlądowych wód powierzchniowych stojących - $\mathrm{w}$ rozumieniu obowiązującej definicji legalnej. Nowelizacja ustawy z 2001 r. o zbiorowym zaopatrzeniu w wodę i zbiorowym odprowadzaniu ścieków powinna iść zaś w kierunku pozwalającym na dookreślenie praw i obowiązków, związanych z wprowadzaniem do urządzeń ka-

nr 173 (2549); T. Żółciak, Deszczówka wypłucze nam portfele, „Gazeta Prawna” 2012, nr 16 (3154).

144 Zob. D. Mucha, Kanalizacja Rawy i otwartych kanatów ściekowych, „Gospodarka Wodna" 2010, nr 5, s. 209-214.

145 Zob. uzasadnienie do wyroku Wojewódzkiego Sądu Administracyjnego w Gdańsku z dnia 21 stycznia 2010 r. - II SA/Gd 606/09, publ. System Informacji Prawnej LEX nr 554116 oraz do wyroku Wojewódzkiego Sądu Administracyjnego w Gliwicach z dnia 31 marca 2011 r. - II SA/Gl 1189/10, publ. System Informacji Prawnej LEX nr 950532.

146 Zob. art. 59 ust. 1-3 ustawy o planowaniu i zagospodarowaniu przestrzennym. 
nalizacyjnych wód opadowych nieposiadających charakteru ścieków. Obowiązujące rozwiązania w tej kwestii są wszak niewłaściwe i budzą wątpliwości w orzecznictwie ${ }^{147}$, wobec czego został już opracowany stosowny projekt zmian legislacyjnych ${ }^{148}$.

Wreszcie, należałoby rozważyć dokonanie korekty obu wspomnianych ustaw oraz Prawa budowlanego z 1994 r., mającej na celu odwrócenie dotychczasowych reguł wprowadzania wód opadowych do urządzeń kanalizacyjnych i odprowadzania do wód powierzchniowych na rzecz pierwszeństwa rozwiązań alternatywnych, pozwalających w szerszym stopniu na wykorzystywanie wód opadowych oraz opóźnienie ich odpływu, a także zwiększenie zasilania przez nie wód podziemnych.

\section{BIBLIOGRAFIA}

Bajkiewicz-Grabowska E., Mikulski Z., Hydrologia ogólna, Warszawa 2008.

Barszcz M., Innowacyjne metody zarzadzania wodami deszczowymi w obszarach zurbanizowanych, „Gaz, Woda i Technika Sanitarna" 2013, nr 1.

147 Zob. B. Rusinek, Projekt ustawy o zmianie ustawy o zbiorowym zaopatrzeniu $w$ wodę $i$ zbiorowym odprowadzaniu ścieków $w$ zakresie wód opadowych. Część I, „Technologia Wody 2013, nr 3, s. 37-40. Taż: Projekt ustawy o zmianie ustawy o zbiorowym zaopatrzeniu $w$ wodę $i$ zbiorowym odprowadzaniu ścieków w zakresie wód opadowych. Część II, „Technologia Wody” 2013, nr 4, s. 44-48.

148 Poselski projekt ustawy o zmianie ustawy o zbiorowym zaopatrzeniu w wodę i zbiorowym odprowadzaniu ścieków został wniesiony do Sejmu w dniu 2 października 2012 r. Przewiduje on wprowadzenie obowiązku uiszczania opłaty również za wody opadowe odprowadzane z powierzchni dachów, której wielkość ma być ustalana na podstawie jednostki miary powierzchni zanieczyszczonej (art. 1 pkt 1 i 2 projektu). Według wnioskodawców projekt stanowi realizację postulatów gmin. Ponadto podnoszą oni, że stosowania w taryfach przelicznika metrów kwadratowych dla odwadnianej powierzchni nie przewiduje dotychczas ustawa, a zatem obowiązujące rozporządzenie Ministra Budownictwa z 28 czerwca 2006 r. jest niekonstytucyjne. W przypadku opłat za wody opadowe $\mathrm{z}$ dachów przyjecie innego miernika obliczeniowego niż metry kwadratowe będzie natomiast w zasadzie niemożliwe. Zob. http://orka.sejm.gov.pl/Druki7ka.nsf/Projekty/7-020-390-2012/\$file/7-020-390-2012.pdf. 
Błaszczyk W., Nowakowska-Błaszczyk A., Projektowanie sieci kanalizacyjnej, [w:] M. Chudzicki (red.), Projektowanie sieci kanalizacyjnej, Warszawa 1971.

Bogacz-Rygas M., Aspekty ekologiczne stosowania nowych rozwiązań odprowadzania wód opadowych $i$ ich zagospodarowanie. Nowe urzadzenia, materiaty $i$ technologie $w$ wodociagach $i$ kanalizacji, Kielce 2007.

Bojarski P., Radecki W., Rotko J., Ustawa o zbiorowym zaopatrzeniu $w$ wodę i zbiorowym odprowadzaniu ścieków. Komentarz, Warszawa 2011.

Burszta-Adamiak E., Sylwester A., Projektowanie dachów zielonych, „Rynek Instalacyjny” 2010, nr 12.

Burszta-Adamiak E., Zagospodarowanie sptywów opadowych za pomoca systemów bioretencji, „Rynek Instalacyjny” 2011, nr 3.

Burszta-Adamiak E., Zrównoważone gospodarowanie wodami opadowy$m i$, „Rynek Instalacyjny” 2010, nr 9.

Bylka H., Skiba J., Uwarunkowania prawne, ekonomiczne i administracyjne zwiazane z pobieraniem optat za wody opadowe, „Gaz, Woda i Technika Sanitarna" 2012, nr 1.

Czetwertyński E., Szuster A., Hydrologia i hydraulika, Warszawa 1973. Dąbrowski W., Parametry fizyczne zawiesin wód deszczowych jako podstawa do projektowania systemów podczyszczania, „Gaz, Woda i Technika Sanitarna" 2001, nr 6.

Dąbrowski W., Rola retencji terenowej $w$ ograniczaniu sptywów powierzchniowych na przykładzie pola golfowego, „Gaz, Woda i Technika Sanitarna" 2007, nr 12.

Dowgiałło J., Kleczkowski A. S., Macioszczyk T., Różkowski A., Słownik hydrogeologiczny, Warszawa 2002.

Dybowski T., Grzybowski S. M., Nowakowski Z. K., Zagadnienia cywilistyczne prawa wodnego, Warszawa 1957.

Dziadkiewicz B., Zbiorowe zaopatrzenie $w$ wodę $i$ odprowadzanie ścieków. Komentarz do przepisów, umowy, taryfy, regulaminy, orzecznictwo, Warszawa 2011.

Glapa W., Korzeniowski J. I., Mały leksykon górnictwa odkrywkowego, Wrocław 2005.

Gruszecki K., Prawo ochrony środowiska. Komentarz, Warszawa 2011.

Gudelis-Matys K., Zagospodarowanie ścieków deszczowych $w$ zakładach przemysłowych, „Magazyn Przemysłu Rybnego” 2004, nr 3.

Gudelis-Taraszkiewicz K., Jak walczyć z powodzią? (1). Retencja wskazana, „Magazyn Instalatora 2010, $\mathrm{nr}$ 7-8.

Gudelis-Taraszkiewicz K., Zagospodarowanie wód opadowych - polskie doświadczenia w eksploatacji komór drenażowych, [w:] Materiaty 
z seminarium pt. Wody opadowe. Status prawny, opłaty, technologie, Gdańsk-Sobieszewo 2006.

Gusta D., Płonka T., Do utrzymania kanalizacji deszczowej nie trzeba dopłacać, „Gazeta Samorządu i Administracji” 2007, nr 9.

Jabłoński E., Wołłejko W., Prawo wodne oraz przepisy wykonawcze i zwiąkowe, Warszawa 1979.

Januchta-Szostak A., Alternatywa dla tradycyjnej kanalizacji?, „Przegląd Komunalny" 2011, nr 11.

Jodłowski A., Mucha J., Ocena możliwości wykorzystania wody szarej, „Gaz, Woda i Technika Sanitarna” 2010, nr 7-8.

Judecki T., Związany charakter decyzji o przywróceniu stanu poprzedniego lub wykonaniu urządzeń zapobiegajacych szkodom na gruntach sąsiednich na skutek dokonanej przez właściciela gruntów zmiany stanu wód na gruncie, „Nowe Zeszyty Samorządowe” 2011, nr 6.

Kałużny M., Prawo wodne. Komentarz, Warszawa 2012.

Kaźmierczak B., Kotowski A., Ocena przydatności dotychczasowych wzorów na natężenie opadów deszczowych do projektowania odwodnień terenów w Polsce, „Gaz, Woda i Technika Sanitarna” 2009, $\mathrm{nr} 11$.

Kaźmierczak B., Kotowski A., O modelowaniu działania kanalizacji deszczowej w terenie płaskim, „Gospodarka Wodna” 2012, nr 7.

Kłoss-Trębaczkiewicz H., Osuch-Pajdzińska E., Zasady ustalania taryf za odprowadzanie wód opadowych i roztopowych do kanalizacji deszczowej, „Gaz, Woda i Technika Sanitarna” 2007, nr 7-8.

Kocewiak A., Nowoczesne sposoby zagospodarowania wody deszczowej, [w:] J. Łomotowski (red.), Wody opadowe a zjawiska ekstremalne. Materiaty konferencyjne z konferencji naukowo-technicznej "Zjawiska ekstremalne w eksploatacji infrastruktury komunalnej” 1-2.02.2011, Warszawa 2011.

Kosiarski M., Czy wolno odprowadzać wodę z dachu na dziatkę sąsiada, „Gazeta Prawna” 2012, nr 11.

Kotowski A., Modele opadów do bezpiecznego projektowania kanalizacji, „Rynek Instalacyjny” 2011, nr 9.

Kotowski A., O potrzebie dostosowania zasad wymiarowania kanalizacji $w$ Polsce do wymagań normy PN-EN 752 i zaleceń Europejskiego Komitetu Normalizacji, „Gaz, Woda i Technika Sanitarna” 2006, nr 6.

Koza I., Osuch-Chacińska L., Pełda-Sypuła M., Rytlewski M., Nowe prawo wodne, Zielona Góra 2002.

Królikowska J., Królikowski A., Wody opadowe. Odprowadzanie, zagospodarowanie, podczyszczanie i wykorzystanie, Warszawa 2012. 
Kryszkiewicz M., Rady gmin wprowadzaja podatek od deszczu, „Gazeta Prawna" 2009, nr 173.

Krzyszczak M., Prawo a odprowadzanie ścieków opadowych, „Wodociągi - Kanalizacja" 2008, nr 4.

Lambor J., Hydrologia inżynierska, Warszawa 1971.

Licznar P., Potrzeba wykorzystania syntetycznych danych opadowych dla modelowania sieci kanalizacji deszczowej i ogólnospławnej, „Gaz, Woda i Technika Sanitarna" 2009, nr 6.

Lipiński A., Z problematyki zadań własnych gminy zwiąanych z zaspokajaniem zbiorowych potrzeb wspólnoty $w$ zakresie gospodarki wodnej, „Samorząd Terytorialny” 1997, nr 5.

Majewski W., Światowy Dzień Wody 2012, „Gospodarka Wodna” 2012, nr 3.

Małecki Z., Ochrona wód. Część VII, „Ekotechnika” 2006, nr 2.

Marczuk M., Koszty wody z nieba. „Gazeta Prawna” 2004, nr 114.

Marszelewski M., Marszelewski W., Problemy własności jezior w Polsce, „Przegląd Prawa Ochrony Środowiska” 2013, nr 3.

Mikosz R., Glosa do wyroku Sądu Najwyższego z dnia 9 lutego 1981 r. I CR 469/80, „Orzecznictwo Sądów Polskich Komisji Arbitrażowych" 1983, z 9.

Mikosz R., Granice przestrzenne nieruchomości, [w:] E. Gniewek (red.), Prawo rzeczowe, Tom 3, Warszawa 2013.

Mikucki Z., Kowalewski J., Ekonomika i prawo wodne, Warszawa 1970. Morawski L., Zasady wykładni prawa, Toruń 2006.

Mucha D., Kanalizacja Rawy i otwartych kanałów ściekowych, „Gospodarka Wodna" 2010, nr 5

Neuman A., Materjalne i formalne prawo wodne, Stanisławów 1930.

Niemiec M., Wiśniowska-Kielian B., Zanieczyszczenie metalami ciężkimi wód sptywajacych z dróg pobranych ze zbiorników odparowujacych, „Inżynieria Ekologiczna” 2008, nr 20.

Nowakowska-Błaszczyk A., Błaszczyk P., Wpływ odprowadzania wód deszczowych z terenów zurbanizowanych na osiągnięcie dobrego stanu ekologicznego wód powierzchniowych, „Gaz, Woda i Technika Sanitarna" 2011.

Odrzywolska A., Potrzebna korekta przepisów, „Przegląd Komunalny” 2012, nr 5.

Osuch-Chacińska L., Komentarz do artykutu „Stup powietrza oblany żelazem czyli o przepustach, rowach $i$ aspektach prawnych uwag i wniosków kilka”, „Gospodarka Wodna” 2013, nr 10.

Osuch-Chacińska L., Przykłady z orzecznictwa, „Gospodarka Wodna” 2010, nr 10.

Piekarski J., Prawo wodne i przepisy wykonawcze, Warszawa 1979. 
Rakoczy B. (red.), Prawo wodne. Komentarz, Warszawa 2013.

Rakoczy B., Własność wód w prawie polskim, „Przegląd Prawa Ochrony Środowiska" 2013, nr 1.

Rakoczy B., Zbiorowe zaopatrzenie $w$ wode $i$ zbiorowe odprowadzanie ścieków $w$ praktyce przedsiębiorstw wodociąowo-kanalizacyjnych, Bydgoszcz 2012.

Rejman W., Stup powietrza oblany żelazem czyli o przepustach, rowach $i$ aspektach prawnych uwag $i$ wniosków kilka, „Gospodarka Wodna" 2013, nr 8.

Rotko J. (red.), Prawo wodne. Komentarz, Wrocław 2002.

Rotko J. (red.), Prawo wodne z komentarzem, Wrocław 1999.

Rudnicki S., O własności wód, „Nowe Prawo” 1982, nr 7-8.

Rusinek B., Projekt ustawy o zmianie ustawy o zbiorowym zaopatrzeniu $w$ wodę i zbiorowym odprowadzaniu ścieków $w$ zakresie wód opadowych. Część I, „Technologia Wody 2013, nr 3.

Rusinek B., Projekt ustawy o zmianie ustawy o zbiorowym zaopatrzeniu $w$ wodę $i$ zbiorowym odprowadzaniu ścieków $w$ zakresie wód opadowych. Część II, „Technologia Wody” 2013, nr 4.

Rybicki Z., Pozwolenie wodno-prawne w systemie gospodarki planowej PRL, Warszawa 1958.

Sakson G., Wykorzystanie wód opadowych w budynkach, „Rynek Instalacyjny" 2010, nr 5, s. 50-53.

Suligowski Z, Gudelis-Taraszkiewicz K., Alternatywne rozwiazania kanalizacji wód opadowych, „Gaz, Woda i Technika Sanitarna” 2003, nr 12.

Surowiec S., Tarasiewicz W., Zwięglińska T., Prawo wodne. Komentarz. Przepisy wykonawcze, Warszawa 1981.

Szachułowicz J., Prawo wodne. Komentarz, Warszawa 2010.

Szer S., O własności wód, „Przegląd Ustawodawstwa Gospodarczego” 1961, nr 2 (152).

Szturc J., Hydrologia stosowana w zarysie, Bielsko-Biała 1995.

Szuma K., Szuma J., Wdrażanie ramowej dyrektywy wodnej $w$ Polsce. Zagadnienia wybrane, [w:] B. Rakoczy (red.), Wybrane problemy prawa wodnego, Warszawa 2013.

Tarasiewicz W., Surowiec S., Rybicki Z., Prawo wodne. Komentarz, przepisy wykonawcze i zwiazkowe, Warszawa 1965.

Tuszko A., Hydraulika i wodociagi, Warszawa 1971.

Ujma A., Analiza wytycznych wymiarowania odwodnień dachowych, „Rynek Instalacyjny” 2009, nr 10.

Wincenciak M., Zmiana stanu wody na gruncie. Analiza prawna art. 29 ustawy Prawo wodne, „Prawo i Środowisko” 2005, nr 4. 
Wiśniewski J., Ustawa o zbiorowym zaopatrzeniu w wodę i zbiorowym odprowadzaniu ścieków z komentarzem, Bydgoszcz 2001.

Zawilski M., Sakson G., Systemy wykorzystywania wody deszczowej $i$ ich wptyw na funkcjonowanie kanalizacji miejskiej, „Gaz, Woda i Technika Sanitarna" 2004, nr 9.

Żukowski P., Degradacja hydrosfery (przegląd problematyki i metod badań), Rzeszów 1994.

Żółciak T., Deszczówka wypłucze nam portfele, „Gazeta Prawna” 2012, nr 16.

Kontakt - e-mail:

swojcik@krakow.rzgw.gov.pl 